\title{
A mass spectrometric platform for the quantitation of sulfur mustard- induced nucleic acid adducts as mechanistically relevant biomarkers of exposure
}

\author{
Tabea Zubel $^{1,2} \cdot$ Sabrine Hochgesand ${ }^{1} \cdot$ Harald John $^{3} \cdot$ Dirk Steinritz $^{3} \cdot$ Annette Schmidt $^{3} \cdot$ Alexander Bürkle $^{1}$. \\ Aswin Mangerich ${ }^{1}$
}

\begin{abstract}
Despite its worldwide ban, the warfare agent sulfur mustard (SM) still represents a realistic threat, due to potential release in terroristic attacks and asymmetric conflicts. Therefore, the rigorous and quantitative detection of SM exposure is crucial for diagnosis, health risk assessment, and surveillance of international law. Alkylation adducts of nucleic acids can serve as valuable toxicologically relevant 'biomarkers of SM exposure'. Here, we developed a robust and versatile bioanalytical platform based on isotope dilution UPLC-MS/MS to quantify major SM-induced DNA and RNA adducts, as well as adducts induced by the monofunctional mustard 2-chloroethyl ethyl sulfide. We synthesized ${ }^{15} \mathrm{~N} /{ }^{13} \mathrm{C}$-labeled standards, which allowed absolute quantitation with full chemical specificity and subfemtomole sensitivities. DNA and RNA mono-alkylation adducts and crosslinks were carefully analyzed in a dose- and time-dependent manner in various matrices, including human cancer and primary cells, derived of the main SM-target tissues. Nucleic acid adducts were detected up to 6 days post-exposure, indicating long persistence, which highlights their toxicological relevance and proves their suitability as forensic and medical biomarkers. Finally, we investigated ex vivo-treated rat skin biopsies and human blood samples, which set the basis for the implementation into the method portfolio of Organization for the Prohibition of Chemical Weapons-designated laboratories to analyze authentic samples from SM-exposed victims.
\end{abstract}

keywords Sulfur mustard $\cdot$ S-lost $\cdot$ Mass spectrometry $\cdot$ DNA damage $\cdot$ Biomarker

\section{Introduction}

Alexander Bürkle

alexander.buerkle@uni-konstanz.de

$\triangle$ Aswin Mangerich

aswin.mangerich@uni-konstanz.de

1 Molecular Toxicology, Department of Biology, University of Konstanz, 78457 Konstanz, Germany

2 Konstanz Research School Chemical Biology, University of Konstanz, 78457 Konstanz, Germany

3 Bundeswehr Institute of Pharmacology and Toxicology, 80937 Munich, Germany

Sulfur mustard (SM) is one of the first chemical warfare agents used in World War I (WWI) (Mangerich and Esser 2014; Steinritz and Thiermann 2016). The use of SM as a warfare agent was first proscribed by the Geneva protocol in 1925 and finally banned by the Chemical Weapons Convention in 1992 (Hoenig 2002; United Nations Treaty Collection 1992). Despite this, SM was broadly used in the Iran-Iraq War (1980-1988) and even recently in asymmetric conflicts, such as in Syria and Iraq (Dons 2013; OPCW 2017; Thiermann et al. 2013). Due to ease of chemical synthesis as well as potentially undestroyed residual stockpiles in conflict areas, it may also be accessible for terroristic groups (BalaliMood and Hefazi 2005; Wang 2010). Therefore, SM still represents a realistic threat, both for civilians and soldiers, which calls for reliable, specific, and sensitive exposure assessment. 
Sulfur mustard is a vesicant, inducing severe skin pathologies within 2-24 h post-exposure, which are characterized by erythema and blisters formed by cell death of keratinocytes and subsequent dermal-epidermal separation. In the long term, this can result in ulceration and pigmentation disorders (Kehe et al. 2009; Steinritz and Thiermann 2016). In addition, the eyes and the respiratory tract are other major targets of SM-induced toxicity (Kehe et al. 2009). Long-term effects include impaired wound healing, chronic suppression of the immune system, and carcinogenesis, such as the development of lung cancers (Balali-Mood and Hefazi 2005; Doi et al. 2011; Hosseini-khalili et al. 2009; Mukaida et al. 2017). Moreover, early on, it was recognized that SM suppresses hematopoiesis and causes bone marrow depletion and leukopenia (Balali-Mood and Hefazi 2005; Krumbhaar 1919; Pappenheimer and Vance 1920; Vedder 1925). This observation led to initial attempts to use SM as an anti-leukemic drug (Adair and Bagg 1931) and later on to the development of nitrogen mustard-based chemotherapeutics, many of which are still in clinical use for the treatment of several types of cancers (Cheung-Ong et al. 2013; Einhorn 1985).

Mechanistically, SM represents a highly reactive compound, which alkylates cellular macromolecules like DNA, RNA, and proteins. It reacts via an episulfonium ion with nucleophilic sites, e.g., nitrogen and oxygen atoms of DNA nucleobases as well as the $C 8$ position of purines. Major molecular targets include guanine at the $N 7$ position, leading to N7-(2-hydroxyethylthioethyl) guanine (N7-HETE-Gua, $\sim 61 \%$ of analyzed adducts), but also the $N 3$ position of adenine, leading to N3-(2-hydroxyethylthioethyl) adenine (N3HETE-Ade, $\sim 16 \%$ of analyzed adducts) (Kehe et al. 2009; Ludlum et al. 1994). The highly mutagenic adduct $O^{6}$-(2-hydroxyethylthioethyl) guanine $\left(O^{6}\right.$-HETE-Gua) was identified only at very low frequencies of $\sim 0.1 \%$ (Fig. 1) (Ludlum et al. 1986). As a bi-functional agent, SM also induces DNA crosslinks, such as bis[2-(guanine-7-yl)ethyl] sulfide
(Bis-Gua, 17\% of analyzed adducts) (Lawley and Brookes 1967). The mono-alkylating analog 2-chloroethyl ethyl sulfide (CEES, also known as half-mustard) is commonly used as a less-toxic and non-restricted surrogate for SMrelated research purposes. Reaction of nucleic acids with CEES leads to N7-(ethylthioethyl) guanine (N7-ETE-Gua) and N7-(ethylthioethyl) adenine (N3-ETE-Ade) adducts. DNA damage is considered the prime causative factor for SM-related toxicities (Batal et al. 2013a; Shakarjian et al. 2010; Yue et al. 2014), by inducing genomic instability, mutations, and cell death, which can result in a sustained inflammation and tumorigenic transformation (Kehe et al. 2008b, 2009; Mangerich et al. 2016; Steinritz and Thiermann 2016). In particular, DNA crosslinks are highly cytotoxic, leading to replication stress and secondary damage, such as DNA double strand breaks (Deans and West 2011).

Immunochemical methods can be used for the rapid and preliminary assessment of SM exposure (Kehe et al. 2008a; Steinritz and Thiermann 2016). However, such methods are limited in their chemical specificity and sensitivity, and exhibit a low linear range of quantitation. Therefore, immunochemical methods are only considered as indicative evidence of SM exposure (Battista et al. 1996). To verify the use of a chemical weapon, the Organization for the Prohibition of Chemical Weapons (OPCW) demands at least two different-ideally independent-bioanalytical methods, preferably based on spectrometric verification by mass spectrometry, and infrared- or nuclear magnetic resonance spectroscopy (Tabassi 2015). In particular, mass spectrometry provides full chemical specificity, high analytical sensitivity, accuracy, and reproducibility, and is, therefore, considered highly suited for exposure verification in court procedures (Remane et al. 2016). One approach to verify SM exposure by mass spectrometry represents the measurement of SM-protein adducts in blood, e.g., serum albumin and hemoglobin, which enables relatively long time windows

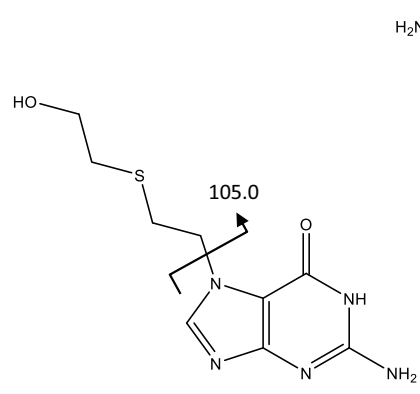

N7-HETE-Gua

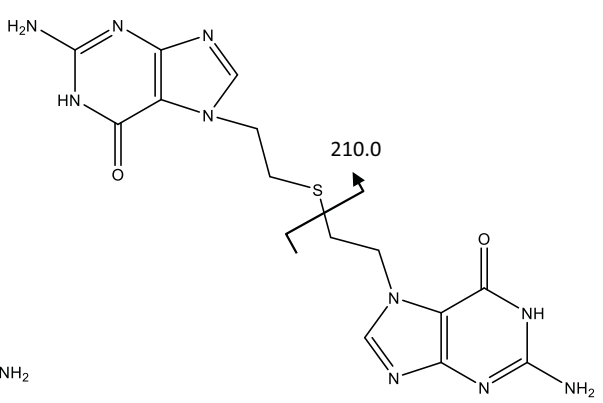

Bis-Gua

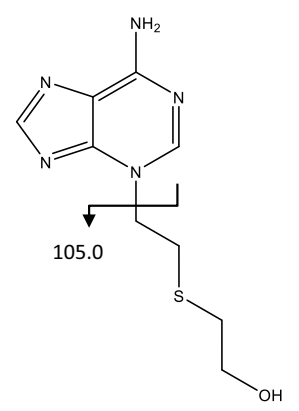

N3-HETE-Ade

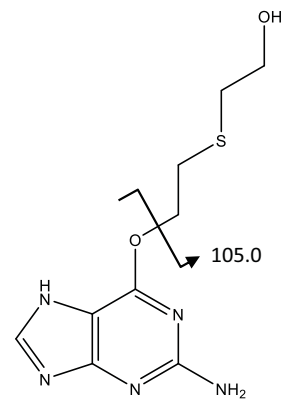

O6-HETE-Gua
Fig. 1 Overview of major SM-induced nucleobase adducts. The main adducts induced by SM are N7-HETE-Gua $\left([\mathrm{M}+\mathrm{H}]^{+} 256.0\right)$, crosslinked Bis-Gua $\left([\mathrm{M}+\mathrm{H}]^{+}\right.$389.3), N3-HETE-Ade $\left([\mathrm{M}+\mathrm{H}]^{+} 240.0\right)$, and $O^{6}$-HETE-Gua $\left([\mathrm{M}+\mathrm{H}]^{+}\right.$256.0). Mono-alkylated adducts are fragmented in MS/MS to a product ion of $[\mathrm{M}]^{+} 105.0$, whereas BisGua results in a fragment of $[\mathrm{M}]^{+} 210.0$ 
of detection of up to 41 day post-exposure (Gandor et al. 2015; John et al. 2016a; Liu et al. 2015; Newmark et al. 2007; Noort et al. 2008; Steinritz et al. 2016). Therefore, blood-derived SM-protein adducts represent well-suited forensic 'biomarkers of exposure'. In comparison to protein adducts, SM-DNA adducts are considered mechanism-based and more toxicologically relevant biomarkers, which would allow health risk assessment, particularly in terms of assessment of cancer risks (Zubel et al. 2018). For absolute quantitation of DNA adducts, isotope-labeled chemical standards can be used, which account for technical variability during sample preparation and mass spectrometric analysis. Such targeted isotope dilution LC-MS/MS (ID-LC-MS/MS) approaches are currently considered the gold standard for the analysis of a broad range of DNA adducts (Tretyakova et al. 2012; Zubel et al. 2018). Thus, mass spectrometric monitoring and quantitation of SM-induced nucleic acid adducts can help to identify and verify exposed individuals, as a method complementing the analysis of SM-protein adduct. In addition, analysis of SM-DNA adducts can set a basis to investigate SM-induced toxicology on a molecular level, thereby contributing to an improved understanding of the mode of action of SM-induced toxicity and the development of effective countermeasures.

Up to now, a limited number of LC-MS/MS approaches to quantify SM-induced DNA adducts have been reported [reviewed in (Zubel et al. 2018)]. Thus, Batal et al. analyzed the three most abundant DNA adducts N7-HETE-Gua, N3HETE-Ade, and Bis-Gua in SM-treated DNA and human leukemic monocytes with limits of detection in the femtomole range (Batal et al. 2013a). The method is based on the use of external calibration curves, by which it lacks the addition of an internal standard for absolute quantitation. Follow-up studies focused on the systemic analysis of adduct distributions in internal organs (Batal et al. 2013b, 2014). Yue et al. quantitatively assessed the four SM adducts N7HETE-Gua, N3-HETE-Ade, Bis-Gua, and $O^{6}$-HETE-Gua (Yue et al. 2014). They used deuterated standards for internal calibration, reaching detection limits in the subfemtomole range. Follow-up studies focused on urinary excretion of metabolites and adduct distributions in different rodent organs (Yue et al. 2015; Zhang et al. 2014). In addition, these authors analyzed adduct levels in adipocyte cell lines and adipose tissue, suggesting a depot effect of SM in lipidrich environments (Wang et al. 2015).

In the current study, we have developed and applied a largely improved and extended mass spectrometric platform based on ID-UPLC-MS/MS for the sensitive, specific, and absolute quantitation of the most relevant mustard-induced DNA and RNA adducts. To this end, we developed methods for sample preparation, chromatographic and mass spectrometric analyses, and the synthesis and purification of ${ }^{13} \mathrm{C},{ }^{15} \mathrm{~N}$-labeled chemical standards. We applied and validated these methods for adduct quantitation in a broad range of biological matrices, including human primary cells and whole blood, as well as rat skin. We carefully examined DNA/RNA adduct levels in a concentration and timedependent manner, proving the suitability of the methods for biomarker analyses and mechanistic studies. Currently, the bioanalytical platform is implemented into the method portfolio of the Institute of Pharmacology and Toxicology of the Bundeswehr, Munich, Germany, which is an OPCWdesignated laboratory, and has already led to the first applications in follow-up research projects (Tsoutsoulopoulos et al., manuscript in preparation).

\section{Materials and methods}

\section{Chemicals}

2-Chloroethyl ethyl sulfide (CEES) was purchased from Sigma-Aldrich. Sulfur mustard (bis-[2-chloroethyl]sulfide, purity $>99 \%$, confirmed by NMR) was made available by the German Ministry of Defense. CEES and SM are highly toxic and carcinogenic. The use of them must be handled with utmost caution. All experiments with SM were performed at the Bundeswehr Institute of Pharmacology and Toxicology, Munich, Germany according to local safety regulations.

\section{Cell culture}

$\mathrm{HaCaT}$ and A549 cells were cultured in DMEM (Thermo Scientific) supplemented with $10 \%$ fetal calf serum (Biochrome) and $1 \%$ penicillin-streptomycin (Thermo Scientific) at $37{ }^{\circ} \mathrm{C}$ in a humidified incubator with $5 \% \mathrm{CO}_{2}$. Cells were washed with PBS (Biochrome) and detached with trypsin-EDTA (0.05\%, Thermo Scientific). Primary normal human epidermal keratinocytes (NHEKs) (adult, pooled, PromoCell) were cultured in Keratinocyte Growth Medium 2 (ready-to-use, PromoCell) at $37{ }^{\circ} \mathrm{C}$ in a humidified incubator with $5 \% \mathrm{CO}_{2}$. Cells were detached using Accutase solution (PromoCell) after washing with HEPES BSS (PromoCell).

\section{SM and CEES treatment of DNA}

One milligram of calf thymus (CT) DNA (Sigma-Aldrich) or baker's yeast RNA (Sigma-Aldrich) were dissolved overnight at $4{ }^{\circ} \mathrm{C}$ in $1 \mathrm{ml} \mathrm{Na}_{2} \mathrm{HPO}_{4}$ buffer (50 mM, pH 7). Solutions of $\mathrm{SM}$ in ethanol (EtOH) or CEES in $\mathrm{EtOH} / \mathrm{HCl}(95 \%$, $\mathrm{v} / \mathrm{v} / 0.5 \%, \mathrm{v} / \mathrm{v})$ were prepared freshly $(200 \times$ of final concentration). Final dilutions were performed in pre-warmed PBS. Solvent controls were treated with $0.5 \%(\mathrm{v} / \mathrm{v})$ solvent in PBS. Incubation was performed for $1 \mathrm{~h}$ at room temperature 
(RT). DNA was precipitated with $350 \mu \mathrm{l}$ isopropanol, centrifuged at $5000 \times g$ for $15 \mathrm{~min}$ at $4{ }^{\circ} \mathrm{C}$, and washed with $250 \mu \mathrm{l}$ cold $\mathrm{EtOH}(70 \%, \mathrm{v} / \mathrm{v})$. Pellets were dried at $37^{\circ} \mathrm{C}$ and resolved in $1 \mathrm{ml}$ TE buffer $(10 \mathrm{mM}$ Tris, $1 \mathrm{mM}$ EDTA, pH 7.9). RNA precipitation was performed with $1.3 \mathrm{ml}$ ice-cold EtOH per $500 \mu \mathrm{l}$ and centrifuged at $10,000 \times g$ for $15 \mathrm{~min}$ at $4{ }^{\circ} \mathrm{C}$. Pellets were washed with $250 \mu \mathrm{l} \mathrm{cold} \mathrm{EtOH} \mathrm{(70 \% ,} \mathrm{v/v)}$ and centrifuged at $13,000 \times g$ for $15 \mathrm{~min}$. Pellets were dried at $37^{\circ} \mathrm{C}$ and resolved in $500 \mu \mathrm{l}$ TE buffer.

\section{SM and CEES treatment of cells}

Pre-mixes of SM in EtOH or CEES in EtOH/HCl (95\%, $\mathrm{v} / \mathrm{v} / 0.5 \%, \mathrm{v} / \mathrm{v})(200 \times$ of final concentration) were prepared freshly. Final dilutions were performed in pre-warmed PBS. Solvent controls were treated with $0.5 \%(\mathrm{v} / \mathrm{v})$ solvent in PBS. Incubation was performed for $1 \mathrm{~h}$ at $37^{\circ} \mathrm{C}$ if not stated otherwise. Cells were washed with pre-warmed PBS and further incubated with fresh medium or directly harvested with trypsin/EDTA, and again washed with cold PBS, and pellets were stored at $-80{ }^{\circ} \mathrm{C}$.

\section{Ex vivo treatment of whole blood samples with SM and CEES}

Blood from healthy volunteers was collected with an S-Monovette $10 \mathrm{ml}$ 9NC (Sarstedt). Blood sample collection was approved by the Ethics Committee of the University of Konstanz. One-milliliter samples were prepared, directly treated with a $200 \times$ pre-mix of CEES or SM, and subsequently incubated for $1 \mathrm{~h}$ at $37{ }^{\circ} \mathrm{C}$. Afterwards, DNA was directly isolated from blood samples or stored at $-80{ }^{\circ} \mathrm{C}$.

\section{Isolation and treatment of PBMCs}

Fresh blood (20-30 ml) was centrifuged at $300 \times g$ for 10 min without brake. Plasma supernatant was discarded. The hematocrit proportion was diluted in pre-warmed PBS to $50 \mathrm{ml}$. A volume of $25 \mathrm{ml}$ of the diluted samples were carefully applied to $15 \mathrm{ml}$ Biocoll (Biochrome). After centrifugation at $900 \times g$ for $15 \mathrm{~min}$ without brake, PBMCs were visible as a white 'cloud' above the Biocoll layer. PBMCs were collected on ice and diluted to $12.5 \mathrm{ml}$ with PBS. After centrifugation at $300 \times g$ for $10 \mathrm{~min}$ at $4{ }^{\circ} \mathrm{C}$, the pellet was washed with cold PBS. Ten million cells were resuspended in $1 \mathrm{ml}$ PBS and treated with CEES. Afterwards, cells were washed with pre-warmed PBS and centrifuged at $800 \times g$ for $5 \mathrm{~min}$. Then, pellets were stored at $-80{ }^{\circ} \mathrm{C}$ or PBMCs were seeded in RPMI medium (Thermo Scientific) with $10 \%$ fetal calf serum (Biochrome) and $1 \%$ penicillin-streptomycin (Thermo Scientific), and incubated at $37{ }^{\circ} \mathrm{C}$ in a humidified incubator with $5 \% \mathrm{CO}_{2}$.

\section{Dried blood spot analysis}

A volume of $200 \mu \mathrm{l}$ of ex vivo-treated blood was spotted on filter blotting paper (Hartenstein, $0.76 \mathrm{~mm}, 330 \mathrm{~g} / \mathrm{m}^{2}$ ) and dried over night at RT. Blood spots were dissolved in $1 \mathrm{ml}$ PBS under agitation overnight at $37^{\circ} \mathrm{C}$. Samples were dried under vacuum and resolved in $200 \mu \mathrm{l}$ PBS and DNA was isolated with the QIAamp DNA blood Mini Kit (Qiagen) according to the manufacturer's instructions and eluted with $100 \mu \mathrm{l}$ TE buffer (10 mM Tris, 1 mM EDTA, pH 7.9).

\section{DNA and RNA extraction}

DNA from whole blood or PBMCs was isolated using the Blood \& Cell Culture DNA Mini Kit (Qiagen) according to the manufacturer's instructions with an additional digestion step with $20 \mu \mathrm{g}$ RNase (DNase and protease-free, Thermo Scientific) at $37^{\circ} \mathrm{C}$ for $1 \mathrm{~h}$, after resuspension of samples in buffer $\mathrm{G} 2$.

DNA and RNA from other cells were isolated using the AllPrep DNA/RNA Mini Kit (Qiagen) including the optional on-column DNase digestion with the RNase-free DNase Set (Qiagen). $\beta$-Mercaptoethanol was added to buffer RLT. Furthermore, an on-column RNase digestion was performed. After washing the AllPrep DNA spin column with buffer AW1, columns were washed with $350 \mu \mathrm{l}$ buffer RW1 and centrifuged for $15 \mathrm{~s}$ at $8000 \times g$. RNase $(20 \mu \mathrm{g})$ was mixed with $80 \mu$ l buffer RDD, applied to the column membrane, and incubated for $30 \mathrm{~min}$ at $30^{\circ} \mathrm{C}$. After washing with $350 \mu \mathrm{l}$ buffer RW1, the purification procedure was continued with buffer AW2 according to the manufacturer's instructions.

RNA from whole blood was isolated using the RNeasy Mini Kit (Qiagen), including the optional on-column DNase digestion. To lyse the blood, $5 \mathrm{ml}$ Red Blood Cell Lysis buffer (15.5 $\mathrm{mM} \mathrm{NH}_{4} \mathrm{Cl}, 1 \mathrm{mM} \mathrm{KHCO}_{3}$, and $10 \mathrm{mM}$ EDTA) was added to $1 \mathrm{ml}$ blood and samples were incubated on ice for $10 \mathrm{~min}$ and vortexed thoroughly. After centrifugation at $400 \times g$ for $10 \mathrm{~min}$ at $4{ }^{\circ} \mathrm{C}$, the pellet was washed with $2 \mathrm{ml} \mathrm{RBL}$ buffer and centrifuged again. Cells were lysed with RLT buffer including $\beta$-mercaptoethanol and homogenized with a QIAshredder according to the manufacturer's instructions.

Cytoplasmatic RNA was isolated from cells using the RNeasy Mini Kit (Qiagen) according to the manufacturer's instructions for the isolation of cytoplasmatic RNA including the lysis of plasma membranes by buffer RLN. Nuclei were removed by centrifugation and used for isolation of nuclear RNA. miRNA was isolated using the HighPure miRNA Isolation Kit (Roche) according to the manufacturer's instructions.

To digest DNA or RNA, a $10 \times$ master mix was prepared with $20 \mathrm{U}$ benzonase nuclease (Sigma-Aldrich) and $40 \mu \mathrm{g}$ DNase I (Roche) or $200 \mu \mathrm{g}$ RNase, respectively, in Tris/ 
$\mathrm{MgCl}_{2}$ (630 mM/63 mM, pH 8). The final concentrations of the buffer in samples were Tris/ $\mathrm{MgCl}_{2}(10.3 \mathrm{mM} / 1 \mathrm{mM})$. Samples were incubated for $2 \mathrm{~h}$ at $37^{\circ} \mathrm{C}$. Afterwards, a mastermix $(10 \times$ concentrated $)$ with $50 \mathrm{U}$ alkaline phosphatase from bovine intestine mucosa (Sigma-Aldrich) and $2.5 \mathrm{U}$ phosphodiesterase I (Affymetrix) was prepared in NaOAc (final concentration $12.4 \mathrm{mM}, \mathrm{pH} 7.8$ ), added to the samples, and incubated for $2 \mathrm{~h}$ at $37^{\circ} \mathrm{C}$. Ultrafiltration was performed with NanoSep Omega 10K centrifugal devices (Pall) for 10 min at full speed. Thermal hydrolysis of DNA adducts was achieved by incubation for $20 \mathrm{~min}$ at $90{ }^{\circ} \mathrm{C}$. RNA was hydrolyzed for $1 \mathrm{~h}$ at $90{ }^{\circ} \mathrm{C}$.

\section{Annexin V/PI analysis}

Five million cells were seeded in 6-well plates 1 day prior to treatment. Twenty-four hours after treatment, medium was collected, and cells were detached. Cells were centrifuged at $1,600 \times g$ for $5 \mathrm{~min}$. Four million cells $/ \mathrm{ml}$ were resuspended in Annexin $\mathrm{V}$ binding buffer (10 mM HEPES, pH 7.4, $140 \mathrm{mM} \mathrm{NaCl}, 2.5 \mathrm{mM} \mathrm{CaCl}_{2}$ ) and $195 \mu$ were stained with $5 \mu$ Annexin V-FITC conjugate (Enzo Life Technologies) for $15 \mathrm{~min}$ in the dark. Afterwards, $200 \mu \mathrm{l}$ PI staining solution $[10 \mu \mathrm{g} / \mathrm{ml}$ PI (Sigma-Aldrich) in Annexin-binding buffer] was added and samples kept on ice until measurement with a FACSVerse instrument (BD Biosciences). Per condition, 20,000 cells were analyzed.

\section{AlamarBlue assay}

Three thousand cells per well were seeded in a 96-well plate in technical triplicates. At the next day, cells were washed with PBS and treated with CEES. After $1 \mathrm{~h}$, cells were washed again with PBS and medium was added. After additional incubation for 24, 48, and 72 h, $10 \mu \mathrm{l}$ AlamarBlue $(10 \times$ concentrated, Thermo Scientific) was added to each well and incubated for $3 \mathrm{~h}$ at $37{ }^{\circ} \mathrm{C}$ in the dark. To stop the reaction, $50 \mu \mathrm{l} \mathrm{SDS} \mathrm{(3 \%} \mathrm{w/v)} \mathrm{was} \mathrm{added;} \mathrm{plates} \mathrm{were}$ sealed and stored at $4{ }^{\circ} \mathrm{C}$ in the dark. Fluorescent signals were detected using a Varioskan Flash reader (Thermo Scientific) (Ex.: $570 \mathrm{~nm} / \mathrm{Em} .: 585 \mathrm{~nm})$.

\section{Immuno slot blot assay}

The protocol was adapted from (Kehe et al. 2013). DNA was diluted to $50 \mu \mathrm{g} / \mathrm{ml}$ in $0.4 \%$ (v/v) formamide and $11.1 \%$ (v/v) formaldehyde in TAE buffer $(20 \mathrm{mM}$ Trizma base, $1.3 \mathrm{mM}$ EDTA, pH 8). Denaturation was performed at $52{ }^{\circ} \mathrm{C}$ for $20 \mathrm{~min}$. Afterwards, samples were stored at $-80{ }^{\circ} \mathrm{C}$. Slots were washed once with PBS and with $6 \times$ SCC buffer (20 $\times$ SCC buffer: $340 \mathrm{mM}$ tri-sodium-citrate, $3 \mathrm{M} \mathrm{NaCl}$ ), DNA was diluted to $1 \mu \mathrm{g}$ in $200 \mu \mathrm{l}$ PBS (1:10), samples were loaded with a negative pressure of 350 mbar on an
Amersham Hybond-N+ membrane (GE Healthcare). Slots were washed with PBS and $2 \times$ SCC buffer. Afterwards, the membrane was air dried for $15 \mathrm{~min}$ and DNA was fixed at $80{ }^{\circ} \mathrm{C}$ for $2 \mathrm{~h}$. The membrane was washed twice with $0.2 \times$ SCC buffer for 15 min and incubated with Dako Protein Block solution (Agilent) for $20 \mathrm{~min}$. The antibody $2 \mathrm{~F} 8$ (TNO, The Netherlands, 1:7000 in Dako Antibody Diluent, Agilent) was applied overnight at $4{ }^{\circ} \mathrm{C}$. After washing thrice with Tris-buffered saline with Tween20 (TBS-T) for $5 \mathrm{~min}$, the membrane was incubated with secondary antibody [goat anti-mouse HRP, Millipore, (1:2000) in milk] for $1 \mathrm{~h}$ at $37^{\circ} \mathrm{C}$, again washed thrice with TBS-T for $5 \mathrm{~min}$, and chemiluminescence was detected via ECL reaction.

\section{Synthesis and validation of analytical standards}

The nucleosides 2'-deoxy-guanosine (dG) or 2'-deoxyadenosine (dA) (unlabeled from Sigma-Aldrich, $800 \mu \mathrm{g} / \mathrm{ml}$ or ${ }^{13} \mathrm{C},{ }^{15} \mathrm{~N}$-labeled from Euriso-Top, $1 \mathrm{mg} / \mathrm{ml}$ in $\mathrm{Na}_{2} \mathrm{HPO}_{4}$ buffer) were treated with $5 \mathrm{mM}$ CEES or $1 \mathrm{mM} \mathrm{SM}$ and incubated for $4 \mathrm{~h}$ at RT and stored at $-20{ }^{\circ} \mathrm{C}$ overnight. Thermal hydrolysis was achieved at $90^{\circ} \mathrm{C}$ for $1 \mathrm{~h}$ and $5 \mathrm{mg}$ treated dG or dA was pre-purified with a Discovery DSC18 SPE tube ( 5 g per $20 \mathrm{ml}$, Sigma-Aldrich). Columns were equilibrated with $8 \mathrm{ml}$ methanol $(\mathrm{MeOH})$ and $8 \mathrm{ml} 1 \%$ $\mathrm{MeOH}(\mathrm{v} / \mathrm{v})$. After sample loading, columns were washed initially with $30 \mathrm{ml} \mathrm{1 \%} \mathrm{MeOH} \mathrm{(v/v)} \mathrm{(20} \mathrm{ml} \mathrm{for} \mathrm{ETE-Ade)}$ and then with $30 \mathrm{ml} \mathrm{5 \%} \mathrm{MeOH} \mathrm{(v/v)} \mathrm{(8} \mathrm{ml} \mathrm{for} \mathrm{ETE-Ade).}$ Elution was performed with $30 \mathrm{ml} 10 \% \mathrm{MeOH}(\mathrm{v} / \mathrm{v})$ and $30 \mathrm{ml} \mathrm{15 \%} \mathrm{MeOH}(\mathrm{v} / \mathrm{v})$, and $16 \mathrm{ml} \mathrm{20 \%} \mathrm{MeOH}(\mathrm{v} / \mathrm{v})$ and $8 \mathrm{ml} 80 \% \mathrm{MeOH}(\mathrm{v} / \mathrm{v})$. Two additional elution steps with $8 \mathrm{ml} \mathrm{MeOH}$ were performed for HETE-Ade. ETE-Ade was additionally washed with $8 \mathrm{ml} \mathrm{15 \%} \mathrm{MeOH} \mathrm{(v/v),} 16 \mathrm{ml} 20 \%$ $\mathrm{MeOH}(\mathrm{v} / \mathrm{v})$, and $16 \mathrm{ml} 20 \% \mathrm{MeOH}(\mathrm{v} / \mathrm{v})$ in 5\% formic acid (v/v). ETE-Ade was eluted with $16 \mathrm{ml} \mathrm{30 \%} \mathrm{MeOH}(\mathrm{v} / \mathrm{v})$ in $5 \%$ formic acid (v/v), $16 \mathrm{ml} \mathrm{40 \%} \mathrm{MeOH}(\mathrm{v} / \mathrm{v})$ in $5 \%$ formic acid (v/v), $16 \mathrm{ml} \mathrm{50 \%} \mathrm{MeOH}(\mathrm{v} / \mathrm{v})$ in 5\% formic acid (v/v), and $8 \mathrm{ml} 80 \% \mathrm{MeOH}(\mathrm{v} / \mathrm{v})$. Columns were regenerated with $8 \mathrm{ml} \mathrm{MeOH}$ and re-used five times.

Final purification was performed on a 2695 Alliance Separation Module (Waters) with a Nucleodur $\mathrm{C}_{18}$ HTec column ( $3 \mu \mathrm{m}, 2 \times 125 \mathrm{~mm}$, Machery-Nagel). ETE-Gua was purified with a gradient starting with $100 \%$ solvent $\mathrm{A}$ (ammonium acetate buffer, $2 \mathrm{mM}$ ) at a flow of $0.2 \mathrm{ml} / \mathrm{min}$. Solvent B (acetonitrile with $0.1 \%$ acetic acid) was increased to $15 \%$ within $25 \mathrm{~min}$, and then further increased to $30 \%$ and held constant for 5 min. ETE-Ade, HETE-Gua, Bis-Gua, and HETE-Ade were purified with a normal or SemiPrep Synergi Fusion-RP column ( $80 \AA$ A $, 4 \mu \mathrm{m}, 250 \times 4.6 \mathrm{~mm} / 250 \times 10 \mathrm{~mm}$, Phenomenex) with a flow of 0.7 or $3.3 \mathrm{ml} / \mathrm{min}$. The gradient started with $100 \% \mathrm{~A}$ and increased within $5 \mathrm{~min}$ to $7.5 \%$ B. After a runtime of $40 \mathrm{~min}, 15 \% \mathrm{~B}$ was reached, further 
increased to $30 \%$ within the next $5 \mathrm{~min}$, and held constant for another $5 \mathrm{~min}$.

$\mathrm{UV} / \mathrm{V}$ is spectra of each adduct were acquired with an Ultrospec 2100 pro spectrophotometer (Amersham Biosciences). Molar extinction coefficients were $\varepsilon_{284}=7400$ $1 \times \mathrm{mol}^{-1} \times \mathrm{cm}^{-1}$ for mono-guanine adducts at $\mathrm{pH} 7$ (Ludlum et al. 1994), $\varepsilon_{270}=17,4001 \times \mathrm{mol}^{-1} \times \mathrm{cm}^{-1}$ for mono-adenine adducts and $\varepsilon_{265}=15,7001 \times \mathrm{mol}^{-1} \times \mathrm{cm}^{-1}$ for Bis-Gua at pH1 (Batal et al. 2013a) were used to calculate concentrations. Product ion scans were performed at a high-end Xevo TQ-S triple quadrupole mass spectrometer (Waters).

\section{Isotope dilution UPLC-MS/MS quantification}

Analyses were performed on an ACQUITY UPLC H-class coupled to a Xevo TQ-S triple quadrupole MS (Waters). An ACQUITY UPLC BEH C18 column $(50 \times 2.1 \mathrm{~mm}$ I.D., $1.7 \mu \mathrm{m}, 130 \mathrm{~A}$, Waters) was used for the chromatographic separation of analytes. For the analysis of RNA, adducts were separated with a flow of $0.8 \mathrm{ml} / \mathrm{min}$. Mobile phase A was Millipore water and B was acetonitrile (LC-MS grade, Carl Roth), both supplemented with $0.01 \%$ formic acid (Sigma-Aldrich). The initial conditions were 100\% A. $\mathrm{B}$ was increased to $5 \%$ until a runtime of ' $2.5 \mathrm{~min}$ ' and held constant until ' 4 min'. Then, B was further increased to $15 \%$ until ' 5 min', to $30 \%$ until ' 5.5 min', and then held constant until ' 6 min'. DNA adducts were separated with a flow of $0.35 \mathrm{ml} / \mathrm{min}$. In an initial gradient, solvent B was increased to $15 \%$ until a runtime of ' 5 min', further increased to $30 \%$ until ' 6 min', and then held constant until ' 7 min'.

The source settings in positive ionization mode were set to: Capillary: $0.7 \mathrm{kV}$, Cone: $11 \mathrm{~V}$, Source Offset: $50 \mathrm{~V}$, Source Temperature: $150{ }^{\circ} \mathrm{C}$, Desolvation Temperature: $500{ }^{\circ} \mathrm{C}$, Cone Gas Flow: $150 \mathrm{l} / \mathrm{h}$, Desolvation Gas Flow: 1000 1/h, Collision Gas Flow: $0.15 \mathrm{ml} / \mathrm{min}$, and Nebuliser Gas Flow: 7 bar. The analyzer was set to high mass resolution.

The analytes were measured with cone voltage of $6 \mathrm{~V}$, collision energy of $10 \mathrm{~V}$, and an auto dwell time $(37 \mathrm{~ms})$ in MRM mode. The following ion transitions $[\mathrm{M}+\mathrm{H}]^{+}$were analyzed: ETE-Ade 224.0 > 89.0, ETE-Gua 240.0 > 89.0, ETE-dA 340.2 > 224.0, ETE-dG 356.2 > 240.0, ETErG 372.1> 240.0, ETE-rA 356.1> 224.0, HETE-Gua $256.0>105.0$, HETE-Ade $240.0>105.0$, Bis-Gua $389.3>210.0$, HETE-dG $372.0>256.0$, HETE-dA $356.2>240.0$, HETE-rG 388.1 > 256.0, and HETE-rA $372.1>240.0$. ' $\mathrm{dG}$ ' and ' $\mathrm{dA}$ ' refer to 2 '-desoxyguanosine and 2'-desoxyadenosine, respectively. ' $\mathrm{rG}$ ' and ' $\mathrm{rA}$ ' refer to guanosine and adenosine, respectively.

DNA and RNA amounts were determined by UPLC-MS/ MS measurements with the same parameters as described for nucleic acid adducts. The following ion transitions $[\mathrm{M}+\mathrm{H}]^{+}$ were analyzed: dG $268.1>152.0$, dA $252.0>136.0$, dT
$243.0>127.0, \mathrm{dC} 228.0>112.0, \mathrm{rG} 284.2>152.0, \mathrm{rA}$ 268.2 > 136.0, rU 245.2 > 113.0, and rC 244.2>112.0.

\section{Method validation}

The linear range of 1-1000 fmol of analytes was determined by serial dilution of standard stock solutions. The LOD and LOQ were determined at the lowest amount detectable at $S / N$ ratios of 3 and 10, respectively. Samples of low-, medium-, and high-quality control concentrations (LQC, MQC, and HQC) were prepared with an amount of 5, 50, and $500 \mathrm{fmol}$ of each adduct, respectively. According to the FDA guidelines (FDA 2005), intraday and interday variations, which are measures for the precision of a method, were determined as $n=5$ for all three concentration levels. Recovery and matrix effects were determined according to the guidelines of the European Medicines Agency (EMA 2011) by preparing three different sets of LQC, MQC, and HQC, each $n=3$. In Set 1, standards were spiked into digested, hydrolyzed blank matrix. In Set 2, standards were spiked into water, and in Set 3, standards were spiked into non-hydrolyzed blank matrix and afterwards hydrolyzed. By dividing the peak areas of Set 3 and Set 1 recovery rates were calculated. The ratio of the peak areas of Set 1-to-Set 2 determined the respective matrix effect. All sets (1-3) were normalized to internal standards. Potential analyte losses due to short-term storage at RT and $37^{\circ} \mathrm{C}$ were determined for 6,12 , and $24 \mathrm{~h}$ of storage. Potential analyte losses due to long-term storage were measured after 2 and 4 weeks of storage at $-20^{\circ} \mathrm{C}$ and $-80{ }^{\circ} \mathrm{C}$. In addition, up to three freeze-thaw cycles were measured. Samples were analyzed in triplicate for LQC, MQC, and HQC.

\section{RESULTS}

\section{Method development and synthesis of internal standards}

To develop chromatographic and mass spectrometric methods for the analysis of the major SM and CEES-induced adducts, isolated calf thymus DNA or yeast RNA was first used as model systems. For sample preparation, DNA or RNA was enzymatically hydrolyzed to nucleotides with benzonase as well as DNase I or RNase A, respectively. Afterwards, nucleosides were generated by incubation with alkaline phosphatase and phosphodiesterase I. For the analysis of a key set of SM and CEES-induced nucleic acid adducts (Fig. 1), appropriate UPLC gradients were developed, resulting in baseline separation of most DNA or RNA adducts from canonical nucleosides with retention times of 4-5 min for CEES-induced DNA adducts, 3-4 min for CEES-induced RNA adducts, and 2-3 min for SM-induced 
DNA and RNA adducts (Suppl. Figure 1). In CEES-treated samples, four nucleoside-derived adducts were detected, i.e., N7-ETE-dG/N7-ETE-rG and N3-ETE-dA/N3-ETE-rA (N.B. $\mathrm{rG}$ and $\mathrm{rA}$ refer to ribonucleosides), as well as spontaneously hydrolyzed nucleobase adducts, i.e. N7-ETE-Gua and N3ETE-Ade. In the case of SM-treated samples, N7-HETEdG/N7-HETE-rG, N3-HETE-dA/N3-HETE-rA, N7-HETEGua, Bis-Gua, and N3-HETE-Ade were detected (Fig. 1). To further improve sensitivity, thermal hydrolysis was performed by incubating DNA samples at $90{ }^{\circ} \mathrm{C}$ for $20 \mathrm{~min}$. Due to the higher stability of the $\mathrm{N}$-glycosidic bond, RNA adducts were hydrolyzed at $90{ }^{\circ} \mathrm{C}$ for $60 \mathrm{~min}$. It is important to note that SM-induced mono-adducts can be unambiguously discriminated from CEES-induced mono-adducts in the mass spectrometric analysis, because of the additional hydroxyl group at the HETE side chain, which is absent in the CEES-induced ETE side chain, leading to a difference in $m / z$ ratios of 16 .

To synthesize suitable internal chemical standards for the absolute quantitation of DNA lesions, ${ }^{13} \mathrm{C}$, ${ }^{15} \mathrm{~N}$-labeled nucleosides were treated with SM and CEES. Pre-purification was achieved by $\mathrm{C} 18$ solid-phase extraction and final purification was performed via HPLC. The chemical standards were characterized by UV/Vis spectroscopy and UPLC-MS/MS fragmentation-induced product ion scans. The absorbance maxima of guanine adducts were at $285 \mathrm{~nm}$, of adenine adducts at $264 \mathrm{~nm}$, and of Bis-Gua crosslinks at $275 \mathrm{~nm}$ (Suppl. Figure 2). Product ion scans of nucleoside adducts led to fragments of their corresponding nucleobase adducts, e.g., (H)ETE-Gua after the fragmentation of $(\mathrm{H})$ ETE-dG, as well as the fragment of the respective alkylating agent, i.e., $[\mathrm{HETE}]^{+}\left(\mathrm{m} / \mathrm{z}\right.$ 105.0) or $[\mathrm{ETE}]^{+}(\mathrm{m} / \mathrm{z}$ 89.0) (cf. Fig. 1). Nucleobase adducts led to $[\mathrm{HETE}]^{+}$or $[\mathrm{ETE}]^{+}$, whereas Bis-Gua led to the expected fragment of $\mathrm{m} / z 210.0$ (Suppl. Figures 3 and 4, cf. Fig. 1).

Calibration curves of unlabeled standards spiked with isotope-labeled standards showed a linear range of detection of at least two orders of magnitudes (Suppl. Figure 5). The sensitivity was determined with a lower limit of detection (LLOD, $S / N=3$ ) of $0.1-0.75 \mathrm{fmol}$ and a lower limit of quantification (LOQ, $S / N=10$ ) of $0.25-1$ fmol, depending to the respective analyte (Table 1). According to the EMA guidelines (EMA 2011), recovery and matrix effects were determined. All values were found to be within the acceptable limits suggested by EMA. Quality controls (QC) were prepared over a low (LQC), medium (MQC), and high (HQC) concentration range of 5, 50 and $500 \mathrm{fmol}$ of each adduct, respectively. The values of percent relative standard deviation (\%RSD), which is a measure for the precision of a method, were within the range of $<20 \%$ for LQCs and of $<15 \%$ for MQCs and HQCs for samples measured on the same day (intraday precision) and on different days (interday precision), except for Bis-Gua measurements, which showed $\%$ RSDs $<30 \%$ (Table 2). These values are fully compatible with FDA guidelines for the validation of analytical procedures (FDA 2005). Furthermore, three rounds

Table 2 Analyses of recovery rates, matrix effects, and precision values

\begin{tabular}{|c|c|c|c|c|}
\hline & \multirow{2}{*}{$\begin{array}{l}\text { Recovery } \\
(\%)(n=3)\end{array}$} & \multirow{2}{*}{$\begin{array}{l}\text { Matrix } \\
\text { effect }(\%) \\
(n=3)\end{array}$} & \multicolumn{2}{|c|}{ Precision (\%RSD) } \\
\hline & & & Interday $(n=5)$ & Intraday $(n=5)$ \\
\hline \multicolumn{5}{|c|}{ HETE-Gua } \\
\hline LQC & 105.0 & 101.2 & 17.4 & 2.5 \\
\hline MQC & 102.2 & 102.4 & $14.5^{\mathrm{a}}$ & 1.3 \\
\hline HQC & 100.0 & 103.5 & 9.9 & 0.9 \\
\hline \multicolumn{5}{|c|}{ HETE-Ade } \\
\hline LQC & 102.3 & 102.6 & 5.1 & 7.3 \\
\hline MQC & 103.6 & 100.1 & 2.3 & 6.2 \\
\hline HQC & 104.3 & 95.6 & 2.5 & 5.6 \\
\hline \multicolumn{5}{|c|}{ Bis-Gua } \\
\hline MQC & 93.2 & 133.9 & 22.3 & 23.3 \\
\hline HQC & 57.7 & 114.9 & 26.0 & 15.7 \\
\hline \multicolumn{5}{|c|}{ ETE-Gua } \\
\hline LQC & 103.2 & 101.4 & 14.2 & 5.5 \\
\hline MQC & 92.7 & 100.8 & $13.0^{\mathrm{a}}$ & 4.7 \\
\hline HQC & 94.6 & 100.2 & $9.0^{\mathrm{a}}$ & $2.5^{\mathrm{a}}$ \\
\hline \multicolumn{5}{|c|}{ ETE-Ade } \\
\hline LQC & 115.9 & 91.1 & 6.3 & 9.5 \\
\hline MQC & 97.9 & 102.1 & $3.7^{\mathrm{a}}$ & 6.1 \\
\hline HQC & 101.2 & 101.0 & $2.0^{\mathrm{a}}$ & $4.7^{\mathrm{a}}$ \\
\hline
\end{tabular}

Recovery and matrix effects of standard substances spiked to blank HaCaT DNA were determined according to EMA guidelines (EMA 2011). Precision was determined according to FDA guidelines (FDA 2005). Standard samples were prepared over a range of 5, 50 and 500 fmol, representing low (LQC), medium (MQC) and high (HQC) concentration quality controls, respectively

${ }^{\mathrm{a}} n=4$ instead of $n=5$

Table 1 Linearity ranges of detection and sensitivity levels

\begin{tabular}{llllll}
\hline & Linear range $(\mathrm{fmol})$ & Calibration curve $(n=3)$ & Linearity $\left(r^{2}\right)$ & LLOD (fmol) & LOQ (fmol) \\
\hline HETE-Gua & $1-1000$ & $y=(1.039 \pm 0.008) x-(0.028 \pm 0.018)$ & 0.9991 & 0.75 & 1 \\
HETE-Ade & $1-1000$ & $y=(0.815 \pm 0.006) x-(0.018 \pm 0.025)$ & 0.9991 & 0.25 & 0.5 \\
ETE-Gua & $1-1000$ & $y=(1.178 \pm 0.007) x-(0.014 \pm 0.015)$ & 0.9993 & 0.1 & 0.25 \\
ETE-Ade & $1-1000$ & $y=(0.4525 \pm 0.003) x-(0.011 \pm 0.012)$ & 0.9993 & 0.1 & 0.25 \\
\hline
\end{tabular}


of successive freeze-thaw cycles as well as short-term and long-term storage did not affect the stability of the tested analytes (Table 3).

The successful validation of the UPLC-MS/MS methods sets the basis for toxicological and mechanistic investigations of SM and CEES-induced nucleic acid damage in several different biological model systems, i.e., isolated DNA/ RNA and nucleic acids isolated from different cell culture models as well as from ex vivo-treated human whole blood samples and rat skin biopsies.

\section{Analyses of SM and CEES-induced nucleobase adducts in isolated DNA and RNA}

The matrices of lowest complexity used in this study were pure nucleic acids, such as isolated CT-DNA and yeast RNA. In these cases, CEES and SM directly reacted with the respective nucleic acid without potential interference of other influencing factors present in cellular systems. CTDNA was treated with increasing concentrations of CEES or SM leading to the formation of the respective DNA adducts in a dose-dependent manner (Fig. 2). Adducts were

Table 3 Analysis of storage stabilities

\begin{tabular}{|c|c|c|c|c|c|}
\hline & \multirow[t]{2}{*}{$\begin{array}{l}\text { Freeze-thaw } \\
\text { (\%RSD) }\end{array}$} & \multicolumn{2}{|c|}{$\begin{array}{l}\text { Short-term stor- } \\
\text { age (\%RSD) }\end{array}$} & \multicolumn{2}{|c|}{$\begin{array}{l}\text { Long-term storage } \\
\text { (\%RSD) }\end{array}$} \\
\hline & & RT & $37^{\circ} \mathrm{C}$ & $-20^{\circ} \mathrm{C}$ & $-80^{\circ} \mathrm{C}$ \\
\hline \multicolumn{6}{|c|}{ HETE-Gua } \\
\hline LQC & 3.9 & 8.1 & 8.7 & 18.7 & 15.9 \\
\hline MQC & 0.4 & 8.4 & 8.9 & 17.7 & 16.1 \\
\hline HQC & 0.0 & 4.9 & 5.2 & 15.1 & 14.2 \\
\hline \multicolumn{6}{|c|}{ HETE-Ade } \\
\hline LQC & 9.3 & 4.4 & 6.6 & 7.7 & 17.8 \\
\hline MQC & 5.2 & 3.6 & 5.2 & 11.4 & 16.3 \\
\hline HQC & 4.6 & 3.2 & 3.4 & 9.8 & 12.3 \\
\hline \multicolumn{6}{|c|}{ Bis-Gua } \\
\hline MQC & 10.7 & 21.6 & 15.2 & 41.1 & 22.2 \\
\hline HQC & 5.8 & 17.8 & 12.3 & 41.7 & 40.4 \\
\hline \multicolumn{6}{|c|}{ ETE-Gua } \\
\hline LQC & 2.1 & 8.8 & 8.9 & 20.7 & 16.4 \\
\hline MQC & 0.6 & 5.0 & 5.6 & 20.0 & 17.9 \\
\hline HQC & 5.4 & 3.5 & 3.3 & 18.3 & 16.0 \\
\hline \multicolumn{6}{|c|}{ ETE-Ade } \\
\hline LQC & 8.2 & 3.3 & 2.1 & 14.3 & 17.8 \\
\hline MQC & 3.6 & 2.7 & 2.4 & 16.2 & 16.3 \\
\hline HQC & 12.6 & 3.4 & 3.6 & 16.8 & 12.3 \\
\hline
\end{tabular}

Analyte stabilities were analyzed after repeated freeze-thaw cycles, short-term storage at ambient temperatures up to $24 \mathrm{~h}$ and long-term storage up to 4 weeks at $-20{ }^{\circ} \mathrm{C}$ and $-80{ }^{\circ} \mathrm{C}$. Standard samples were prepared over a range of 5, 50, and $500 \mathrm{fmol}$, representing low (LQC), medium (MQC) and high (HQC) concentration quality controls, respectively detectable at concentrations $\geq 10$ nM CEES (Fig. 2a) and $>100$ nM SM (Fig. 2b). Furthermore, several SM-induced DNA crosslinks were identified, such as previously reported Bis-Gua, but also two so far unreported adducts, i.e., crosslinks of guanine and adenine (Gua-ETE-Ade) and of two adenines (Bis-Ade) (Suppl. Figure 6A). Treatment with $100 \mu \mathrm{M}$ CEES resulted in molar percentages of $60 \%$ ETEGua and 40\% ETE-Ade, whereas SM treatment resulted in the induction of $81.3 \%$ HETE-Gua and $18.7 \%$ HETE-Ade. Similarly, in yeast RNA, CEES and SM-induced adducts were detectable in a concentration-dependent manner with similar sensitivities as observed in DNA, i.e. $\geq 10 \mathrm{nM}$ CEES and $\geq 100 \mathrm{nM} \mathrm{SM}$ (Fig. 3a, b). Compared to DNA, the percentages of ETE-Gua and HETE-Gua were higher, i.e., 96\% and $99 \%$, respectively. To compare our MS-based method with a completely independent method for the detection of SM and CEES-induced DNA adducts, immunochemical detection with the 2F8 antibody against (H)ETE-Gua was performed (Kehe et al. 2013). Statistically significant DNA adduct induction was visible after treatment with $500 \mu \mathrm{M}$ CEES and $100 \mu \mathrm{M} \mathrm{SM}$ (Fig. 2c, d). In RNA, treatment with $\geq 100 \mu \mathrm{M}$ CEES and SM resulted in statistically significant adduct induction (Fig. 3c, d). Our mass spectrometric approach is, therefore, 3-4 orders of magnitudes more sensitive than the immunochemical detection. Furthermore, the UPLC-MS/MS-based detection exhibits full chemical specificity without the limitation of potential antibody cross-reactivity.

In a next step, DNA adducts were examined in the keratinocyte cell line, $\mathrm{HaCaT}$, and in the lung carcinoma cell line, A549, which as skin- and lung-derived cells represent the most relevant SM-target tissues. Cellular systems consist of a more complex matrix than isolated DNA, since the toxicant has to pass several membranes to reach nuclear DNA, thereby potentially leading to lower effective concentrations. Moreover, DNA and RNA must be isolated from cells, which potentially lead to some loss of the analytes. In both cellular systems, DNA adducts were detectable after treatment with $\geq 100$ nM CEES (Fig. 4a, b). In HaCaT cells, ETE-Gua and ETE-Ade adducts were induced at relative frequencies of $75.1 \%$ and $24.9 \%$, respectively. In A549 cells, ETE-Gua and ETE-Ade adducts were induced at relative frequencies of $94.6 \%$ and $5.4 \%$, respectively. After SM treatment, DNA adducts were detectable after treatment with $\geq 100$ nM SM (Fig. 4c, d). The molar percentage of HETEGua and HETE-Ade in HaCaT and A549 cells were about 89-90\% and 10-11\%, respectively. Interestingly, CEES induced about five-to-tenfold more mono-alkylated adducts than SM, suggesting different toxicokinetics and dynamics of the two substances. In addition, in both cell lines, RNA adducts were investigated (Fig. 5). The detection limits corresponded to treatment concentrations of $100 \mathrm{nM}$ CEES and SM, which was in the same range as for cellular DNA. 
A

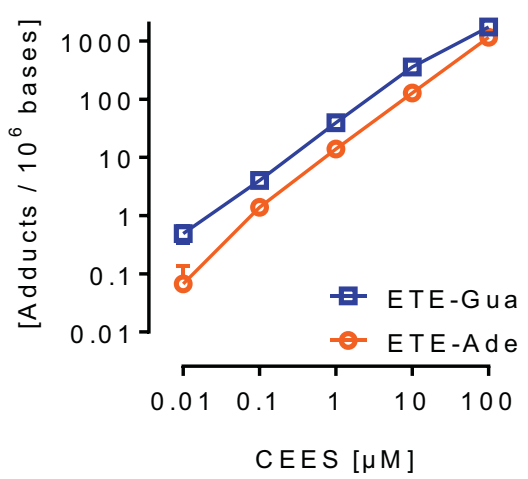

C

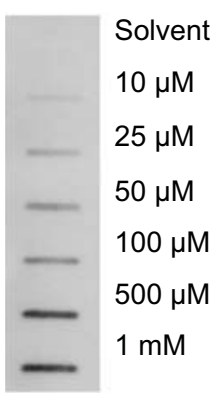

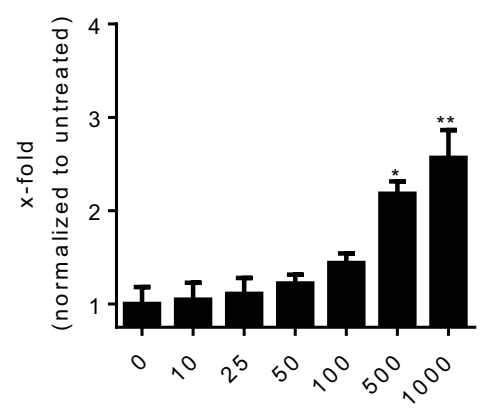

CEES $[\mu \mathrm{M}]$
Fig. 2 SM and CEES-induced nucleobase adducts in isolated CTDNA. CT-DNA was treated with indicated concentrations of CEES or SM for $1 \mathrm{~h}$. a Dose-response relationship of CEES-induced ETEGua and ETE-Ade. Adducts were detected at concentrations $>10 \mathrm{nM}$ CEES. Means \pm SEM of $n=3$. b Dose-response relationship of SMinduced HETE-Gua and HETE-Ade. Adducts were detected at con-

In both cell lines, RNA adducts occurred at a distribution of 95\% ETE-Gua and 5\% ETE-Ade after CEES treatment, whereas SM induced an even higher percentage of HETEGua of $98.6 \%$. In addition, nucleobase adducts were analyzed in different RNA pools, such as RNA extracted from the nucleus, i.e. mainly rRNA, the cytoplasm, including mRNA and tRNA, as well as in miRNA (Suppl. Figure 7). Between the different RNA pools, no considerably differences were observed.

\section{Time-course analyses of adduct stability in different cellular in vitro systems}

To gain insights into the kinetics of adduct induction and repair, time-course analyses were performed in $\mathrm{HaCaT}$ and A549 cells. Appropriate doses were chosen according to toxicity testing via AlamarBlue and cell death staining. In both cell lines, $100 \mu \mathrm{M}$ CEES did not significantly affect cell viability for up to 3 days (Suppl. Figure 8). In addition, AnnexinV/PI staining revealed no increased cytotoxicity after treatment with $100 \mu \mathrm{M}$ CEES for $24 \mathrm{~h}$ up to 3 days
B

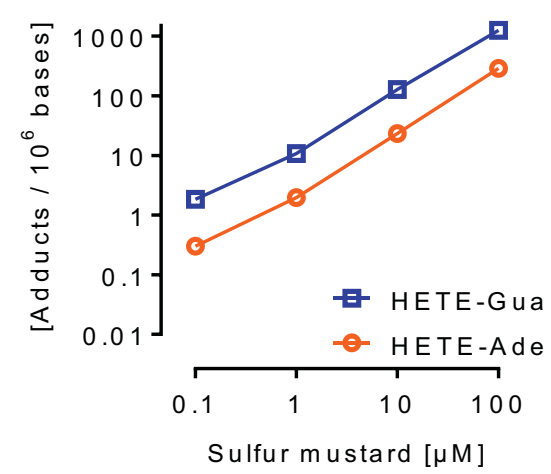

D
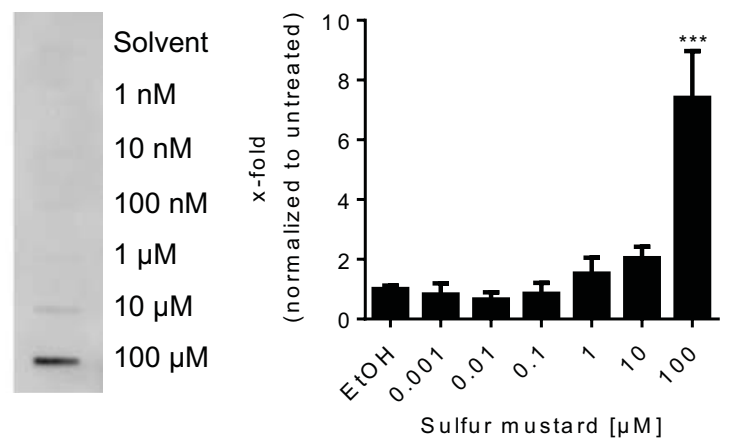

centrations $\geq 100 \mathrm{nM}$ SM. $n=1$. Immunochemically slot-blot detection of CEES (c) and SM (d) induced DNA adducts using the $(\mathrm{H})$ ETE-Gua-specific antibody $2 \mathrm{~F} 8$. Data are means \pm SEM relative to control mean of three independent experiments. Statistical analysis was performed using one-way ANOVA followed by a post hoc Bonferroni test. $* p<0.05, * * p<0.01, * * * p<0.001$

(Suppl. Figure 9). Therefore, $100 \mu \mathrm{M}$ CEES was considered as a suitable concentration for long-term treatment. For reasons of comparability, we also chose a concentration of $100 \mu \mathrm{M}$ SM, although, at this dose, some cytotoxicity has been observed (Mangerich et al. 2016), which needs to be considered, when interpreting the data.

CEES treatment led to a rapid adduct induction already 5 min after treatment, whereas SM treatment led to a further increase in adduct levels up to $1 \mathrm{~h}$ after treatment (Fig. 6). Afterwards, a constant decrease in adduct levels was observed, but DNA adducts were still clearly detectable at least for 6 days after treatment, in particular in the case of SM-treated samples. The half-life $\left(\tau_{1 / 2}\right)$ values of HETE-Gua were determined to be $23.4 \mathrm{~h}$ and $69.5 \mathrm{~h}$ in $\mathrm{HaCaT}$ and A549 cells, respectively. $\tau_{1 / 2}$ of Bis-Gua was $49.7 \mathrm{~h}$ in HaCaT cells and $34.1 \mathrm{~h}$ in A549 cells. $\tau_{1 / 2}$ of HETE-Ade was $11.6 \mathrm{~h}$ in $\mathrm{HaCaT}$, whereas $23.5 \mathrm{~h}$ in A549 cells. Although to a lower extent, CEES adducts were also still detectable 6 days after treatment, exhibiting $\tau_{1 / 2}$ values in HaCaT and A549 cells of $21.7 \mathrm{~h}$ and $19.6 \mathrm{~h}$ for ETE-Gua, respectively, and $14.2 \mathrm{~h}$ or $7.1 \mathrm{~h}$ for ETE-Ade, respectively. Since cells were still 
A

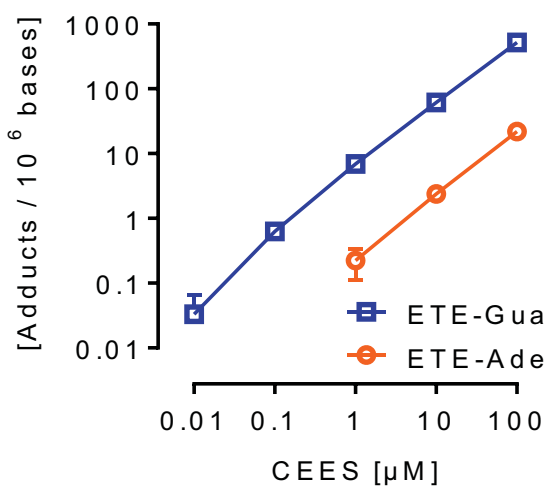

C

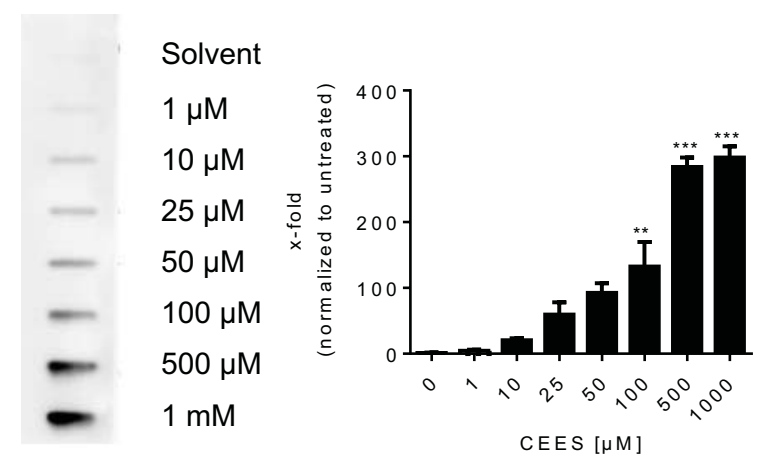

Fig. 3 SM and CEES-induced nucleobase adducts in isolated yeast RNA. Yeast RNA was treated with indicated concentrations of CEES or SM for $1 \mathrm{~h}$. a Dose-response relationship of CEES-induced ETEGua and ETE-Ade. Adducts were detected at concentrations $\geq 10 \mathrm{nM}$ CEES. Means \pm SEM of $n=3$. b Dose-response relationship of SMinduced HETE-Gua and HETE-Ade. Adducts were detected at con-

proliferating (Suppl. Figure 10), the decrease of adducts might at least in part be due to dilution of unrepaired adducts by newly synthesized DNA. As compared to DNA adducts, similar results were obtained for RNA adducts. Thus, after CEES treatment adduct levels peaked already after $5 \mathrm{~min}$ (Fig. 7a, b), whereas, after SM treatment, adduct levels increased until $1 \mathrm{~h}$ post-treatment (Fig. 7c, d). In all cases, sustained adduct stability was evident, as signals were still clearly detectable 6 days after treatment, suggesting slow turnover of damaged RNA. For CEES-induced RNA adenine adducts, $\tau_{1 / 2}$ values of ETE-Ade were $14.3 \mathrm{~h}$ and $12.1 \mathrm{~h}$ in $\mathrm{HaCaT}$ and A549, respectively. For presently unknown reasons, SM-induced RNA adenine adducts were not reliably detectable in both cell lines. ETE-Gua instead showed $\tau_{1 / 2}$ values of $20 \mathrm{~h}$ and $18.8 \mathrm{~h}$ in $\mathrm{HaCaT}$ and $\mathrm{A} 549$ cells, respectively, whereas HETE-Gua showed $\tau_{1 / 2}$ values of $66.3 \mathrm{~h}$ and $35.5 \mathrm{~h}$ in $\mathrm{HaCaT}$ and A549 cells, respectively.

Both, for DNA as well as for RNA adducts, a rather slow decay of adducts was observed, indicating slow turn-over of adducts in both types of nucleic acids. Similar results
B

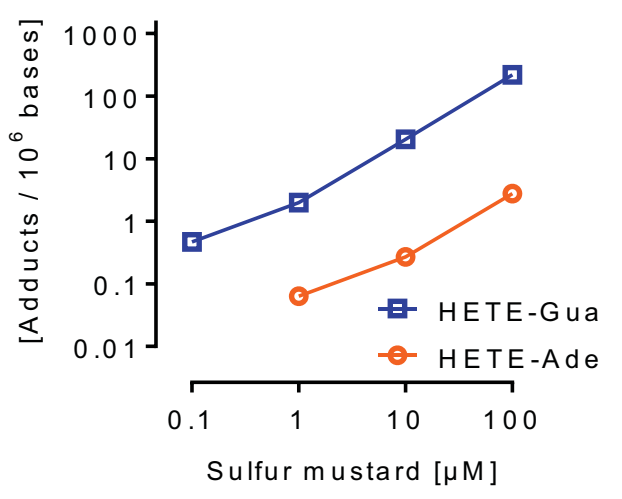

D

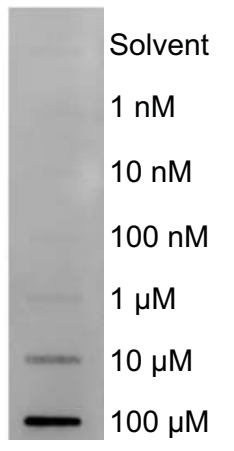

centrations $\geq 100 \mathrm{nM}$ SM. $n=1$. Immunochemically slot-blot detection of CEES (c) and SM (d) induced RNA adducts using the $(\mathrm{H})$ ETE-Gua-specific antibody $2 \mathrm{~F} 8$. Data are means \pm SEM relative to control mean of three independent experiments. Statistical analysis was performed using one-way ANOVA followed by a post hoc Bonferroni test. $* p<0.05, * * p<0.01, * * * p<0.001$

were obtained in other cell lines, such as HepG2, HeLa, and Jurkat cells (data not shown), suggesting cell line independent mechanisms for the sustained adduct stability. Since immortalized cell lines might exhibit dysregulated DNA repair mechanisms, in a next step, we employed primary cells, which are considered fully repair proficient, for timecourse analyses.

\section{Quantitative analyses of CEES-induced DNA adducts in primary cells and ex vivo-treated tissues}

To investigate the stability of SM- and CEES-induced adducts in primary cells, human peripheral blood mononuclear cells (PBMCs) and normal human epidermal keratinocytes (NHEKs) were examined. Freshly isolated PBMCs were successfully cultivated ex vivo for up to 3 days. NHEKs were cultivated for at least 15 population doublings corresponding to about 25 days. Dose-dependent adduct induction was examined in both cell types. In NHEKs, adduct induction was similar as in cancer cell lines. In contrast, 
Fig. 4 Quantitation of DNA nucleobase adducts isolated from SM and CEES-treated $\mathrm{HaCaT}$ and A549 cells. Each cell line was treated with the indicated concentrations of CEES or SM for $1 \mathrm{~h}$. After DNA isolation, internal standards were spiked into the samples, which enabled absolute adduct quantification per 1 million canonical bases. HaCaT (a) or A549 (b) cells were treated with CEES Adducts were detectable after treatment of $\geq 100 \mathrm{nM}$ CEES $\mathrm{HaCaT}(\mathbf{c})$ or A549 (d) cells were treated with SM. Adducts were detected at concentrations $\geq 100 \mathrm{nM}$ SM. Data in $\mathbf{a}$ and $\mathbf{b}$ represent means of $n=3 \pm$ SEM; data in $\mathbf{c}$ and $\mathbf{d}$ are from one experiment, respectively
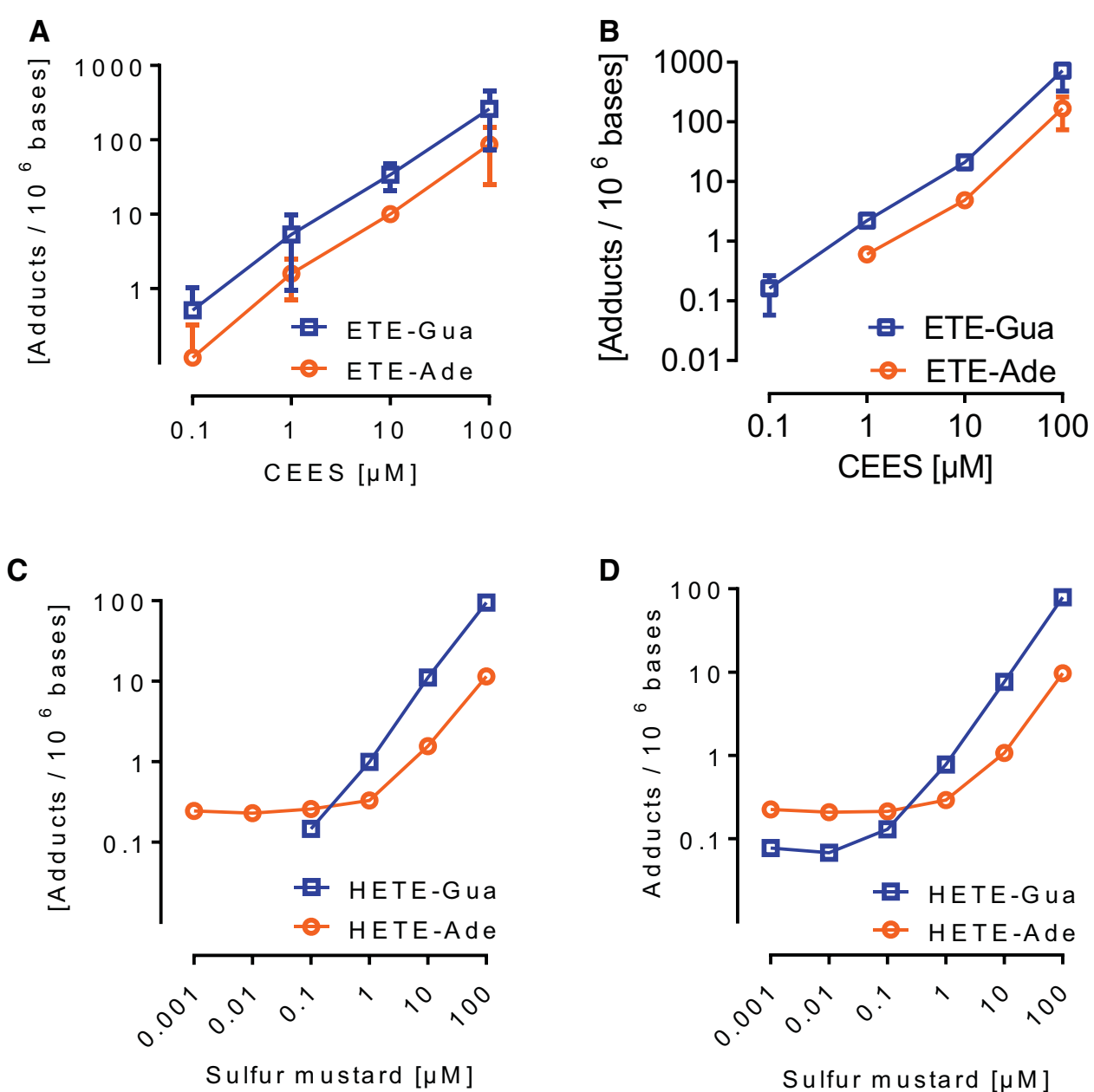

D

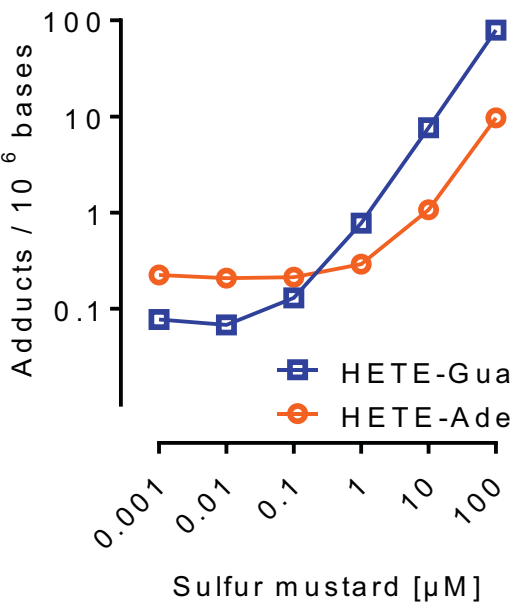

a seven-to-eightfold higher adduct induction was observed in PBMCs (Fig. 8). Similar results were observed for RNA adducts in NHEKs (Suppl. Figure 11A). As compared to cancer cell lines, both cell types were more sensitive against CEES, since already $100 \mu \mathrm{M}$ CEES induced cytotoxic effects (Suppl. Figure 12). Therefore, we chose a sublethal dose of $10 \mu \mathrm{M}$ CEES for time-course studies up to 3 days (Fig. 8b, d and Suppl. Figure 11B). In both cell types, sustained adduct stability was detected, as especially in PBMCs about onehalf to one-third of the adducts were detectable 3 days postexposure. Since PBMCs are non-proliferative cells, in this case, a dilution effect due to DNA replication, as it is possible in cancer cell lines, can be excluded and adduct decay should occur exclusively due to DNA repair and potential cell loss. Therefore, these results suggest long adduct persistence, due to insufficient repair and/or delayed release of reactive molecules from subcellular reservoirs.

To verify SM exposure in different relevant biological sample matrices, protocols for the purification of nucleic acid adducts from ex vivo-treated human whole blood samples (including dried blood spots) and rat skin samples were established. Adduct verification in ex vivo-treated human whole blood was achieved in DNA (Fig. 9), as well as in RNA (Suppl. Figure 13). As simultaneous isolation of DNA and RNA was not possible, a separate protocol for the isolation of RNA from blood was employed. The observed dose-response relationships were consistent with those observed in PBMCs (Fig. 9a). Again, about 11- to 12-fold more adducts were induced by CEES treatment in blood cells compared to other cell types (Fig. 9b). As blood components as well as cell types and numbers may vary between different human individuals or the time point of blood collection, the assay variability was tested by analyzing one donor at five different days (intradonor or interday variability, Fig. 9c) and five different donors (interindividual variability, Fig. 9d). Treatment with $10 \mu \mathrm{M}$ CEES showed low variability in both data sets, which proved the robustness and suitability of the method for the analysis of blood samples.

Dried blood spots represent one of the easiest and most robust sampling procedures for subsequent biomarker analyses, since only low amounts of blood are necessary, and sampling can be conducted in remote and hard to reach geographical areas without the need of any special medical equipment. Furthermore, after drying, blood is assumed 
Fig. 5 Quantitation of RNA nucleobase adducts isolated from SM and CEES-treated $\mathrm{HaCaT}$ and A549 cells. Each cell line was treated with the indicated concentrations of CEES or SM for $1 \mathrm{~h}$. After RNA isolation, internal standards were spiked into samples, which enabled absolute adduct quantification per 1 million canonical bases. HaCaT (a) or A549 (b) cells were treated with CEES. Adducts were detected at concentrations of $\geq 100 \mathrm{nM}$ CEES in HaCaT (a) or A549 (b). HaCaT (c) or A549 (d) cells were treated with SM. Adducts were detected at concentrations of $\geq 100 \mathrm{nM}$ SM. Data in $\mathbf{a}$ and $\mathbf{b}$ represent means of $n=3 \pm$ SEM, data in c and $\mathbf{d}$ are from one experiment, respectively
A

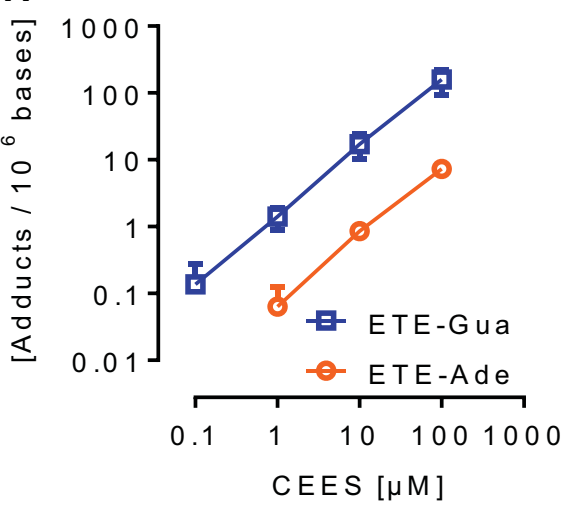

C

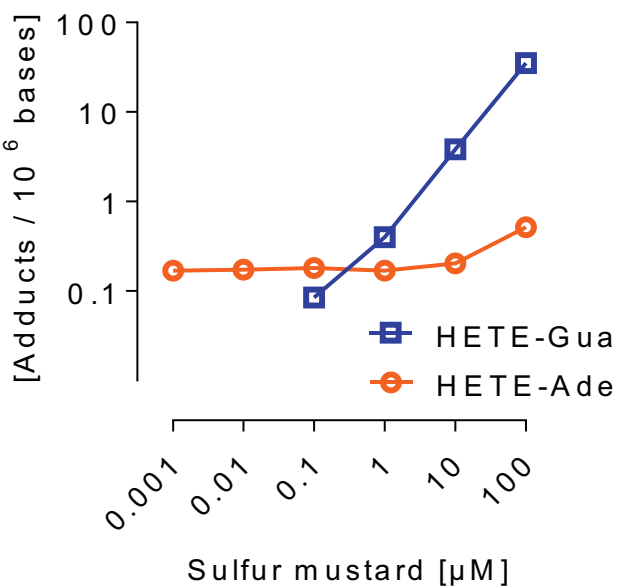

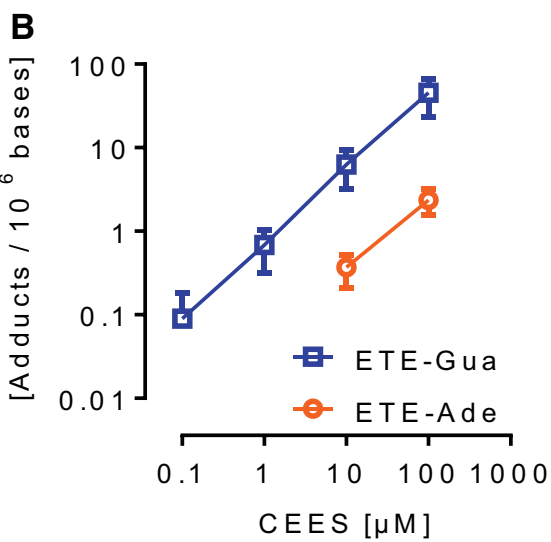

D

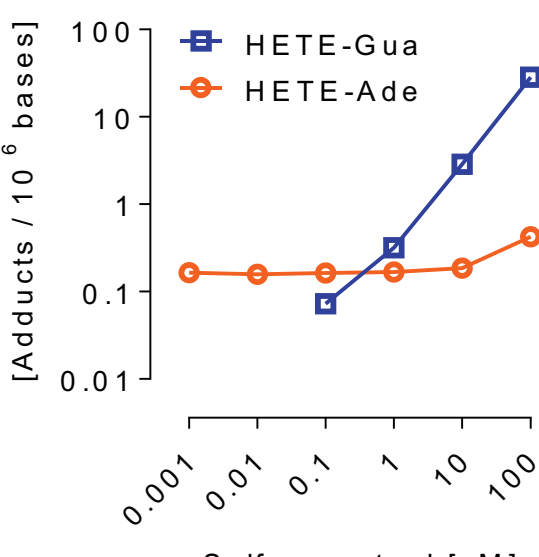

to be non-infectious, which allows convenient shipping of the sample material without cooling and sophisticated biological safety measures. A recent study has demonstrated the suitability of this sampling procedure for the analysis of SM-protein adducts as biomarkers of exposure (John et al. 2016b). Due to the high chemical stability of DNA at ambient temperatures, the dried blood spot method is expected to be equally well suited for the analysis of SM-DNA adducts. To test if our mass spectrometric platform can be combined with the dried blood spot analysis, we performed proof-ofprinciple experiments using $200 \mu \mathrm{l}$ ex vivo-treated blood samples spotted on a filter paper and dried overnight at room temperature. Afterwards, blood spots were resolved in PBS, and DNA was isolated via a commercially available DNA extraction kit. Of note, limits of detection were only tenfold higher compared to the analysis of fresh blood samples, as DNA adducts could be clearly detected after treatment with $\geq 1 \mu \mathrm{M}$ CEES (Fig. 10a). The higher detection limits can be explained by the different sample matrix and, therefore, altered DNA isolation efficiency, but also by the lower amount of blood used for the analysis. Since all blood-based analyses are restricted to the life span of DNAcontaining blood cells, we additionally tested skin samples. In this case, a longer detection window can be assumed compared to blood as well as higher adduct induction, due to direct contact with SM. For this reason, again, proofof-principle studies were performed with rat skin, treated ex vivo with CEES or SM and afterwards stored at $-20{ }^{\circ} \mathrm{C}$. Tissue was homogenized and DNA was isolated. In rat skin treated with the lowest tested concentrations of CEES (i.e., $400 \mu \mathrm{M}$ ) or SM (i.e., $40 \mu \mathrm{M}$ ) DNA adducts were clearly detectable (Fig. 10b, c). The higher detection limits may be due to dilution effects from unexposed surrounding tissue.

\section{Discussion}

In this study, we developed and applied a novel bioanalytical platform based on ID-UPLC-MS/MS for the quantitation of major SM- and CEES-induced nucleic acid adducts. These methods enable the absolute quantitation of DNA- as well as RNA adducts as mechanistically relevant biomarkers in a broad range of biological sample material, including blood samples and skin biopsies.

Non-radioactive, isotope-labeled internal standards were synthesized from ${ }^{13} \mathrm{C} /{ }^{15} \mathrm{~N}$-labeled nucleosides. Dual-labeled standards at the site of the nucleobase are considered the most suitable standards, as the isotope incorporation is more 
A
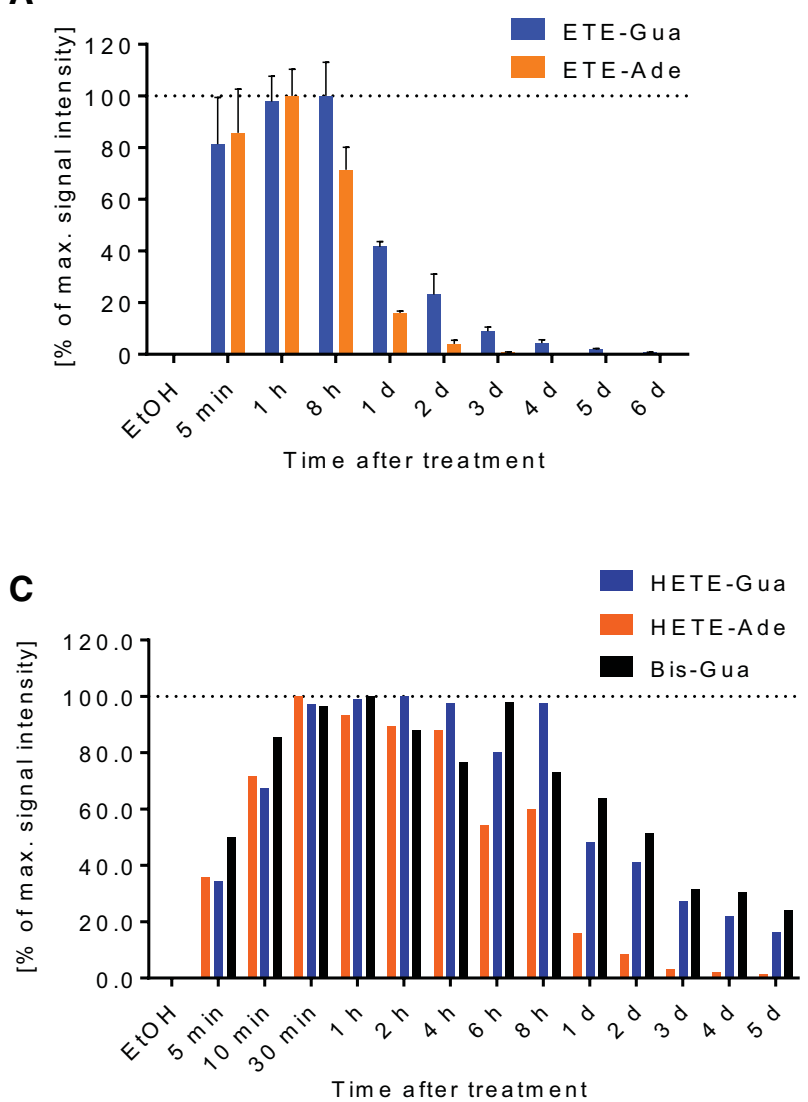

Fig. 6 Time-course analyses of DNA nucleobase adducts isolated from SM and CEES-treated HaCaT and A549 cells. Cells were treated with $100 \mu \mathrm{M}$ CEES (a, b) or $100 \mu \mathrm{M}$ SM (c, d) for $5 \mathrm{~min}$. Recovery of cells was allowed for the indicated time points up to 6 days post-treatment. Upon CEES treatment, rapid adduct formation was observed in HaCaT (a) and A549 (b) cells. Only a slight decrease was detected until the first day. Afterwards constant decay in adduct levels was observed, but adducts were clearly detect-

stable compared to deuterated standards. Deuterated standards are cheaper, as they are derived by exchange synthesis; however, for this reason, they are also prone to re-exchange with normal isotope atoms resulting in loss of the isotope label (Stokvis et al. 2005). Furthermore, deuterated standards can lead to a shift in retention times as, sometimes, deuterated analytes elute before the non-labeled analyte and, therefore, potentially show different properties during the MS analysis (Iyer et al. 2004). In the current study, the standards of N7-(H)ETE-Gua and N3-(H)ETE-Ade were successfully synthesized and characterized by the signature of their UV/Vis spectra and mass spectrometric product ion scans. In addition, Bis-Gua standard has been successfully synthesized; however, for technical reasons, the obtained yield and quality has been too low for its use in absolute adduct quantitation. In our hands, enzymatic hydrolysis of DNA to nucleosides and subsequent thermal hydrolysis was
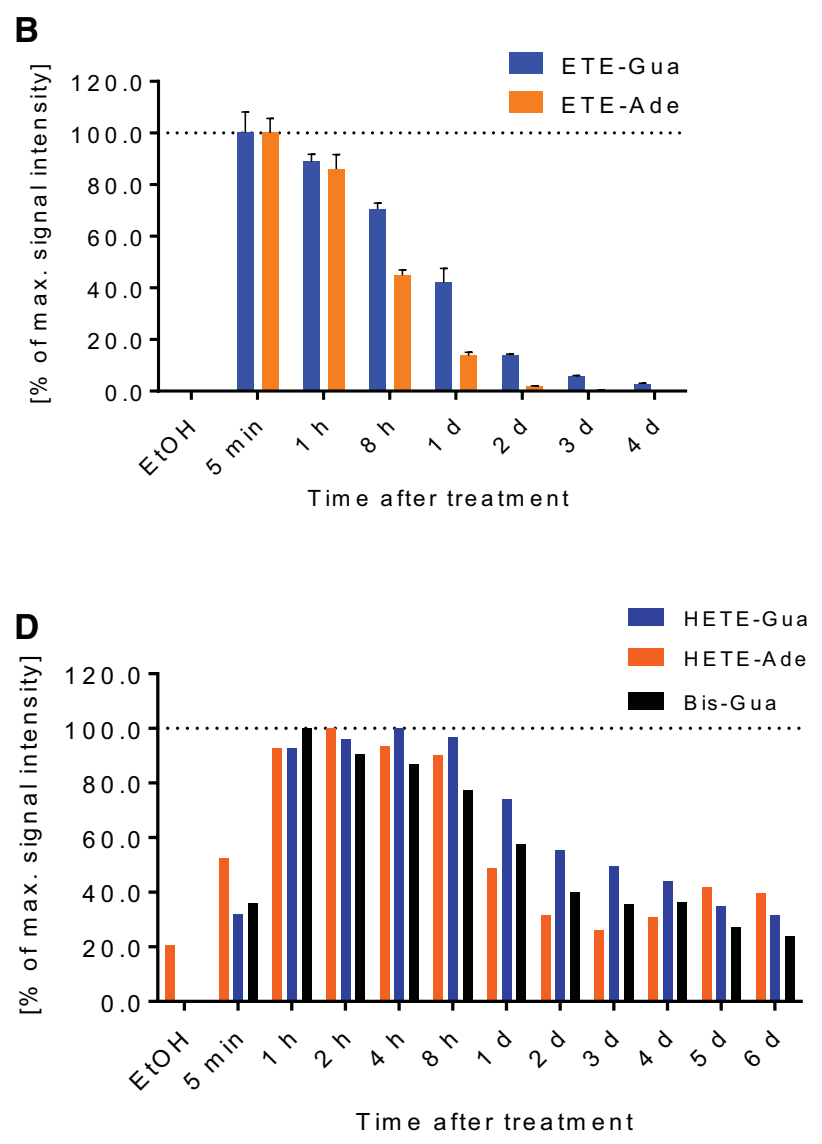

able 6 days after exposure. HaCaT (c) and A549 cells (d) were treated with SM and incubated for the indicated periods. An increase in adduct levels was observed until $1 \mathrm{~h}$ post-treatment. Compared to CEES-induced adducts, SM-induced adducts were more stable and clearly detectable up to 6 days after exposure. Data in a and b represent means \pm SEM of three independent experiments. Data in $\mathbf{c}$ and $\mathbf{d}$ are from one experiment

the best choice for adduct analysis, because enzymatic digestion allowed very precise quantitation of canonical bases in a sample by concurrent UPLC-MS/MS measurements, which is necessary for normalization of the adduct levels, and thermal hydrolysis further increased the sensitivity of the method. Further validation of our MS platform demonstrated high linearity and sensitivity without any interfering matrix effects and high stability of the analytes in short-term and long-term storage experiments.

Adducts in isolated CT-DNA were detected at treatment concentrations of $\geq 10 \mathrm{nM}$ CEES and $\geq 100 \mathrm{nM} \mathrm{SM}$. In cell culture models, adducts were detected at treatment concentrations $\geq 100 \mathrm{nM}$ of CEES and SM, which is slightly higher than in isolated DNA and can be presumably attributed to the buffering capacity of cell membranes and other cellular components, such as GSH. With this, our newly developed UPLC-MS/MS methods display higher sensitivity and 

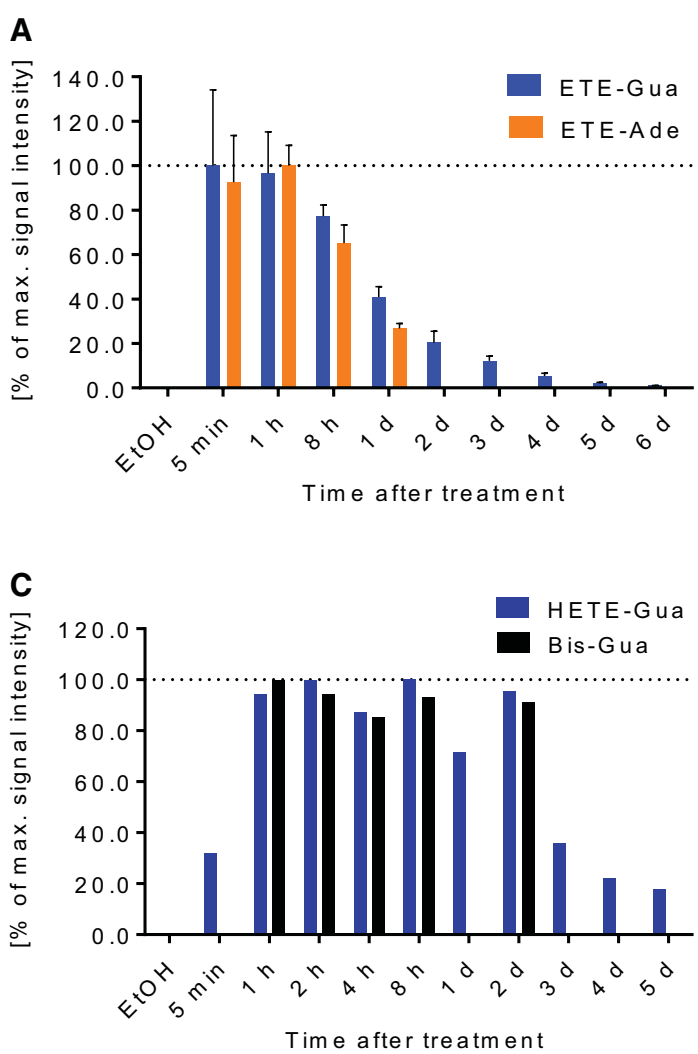

Fig. 7 Time-course analyses of RNA nucleobase adducts isolated from SM and CEES-treated HaCaT and A549 cells. HaCaT (a, c) or A549 (b, d) cells were treated with $100 \mu \mathrm{M}$ CEES or SM for 5 min and further incubated for the indicated time points. a, b CEES treatment led to rapid adduct induction with peak adduct levels already 5 min after treatment, followed by a constant decay of adducts until

specificity than immunohistochemically methods using the N7-HETE-Gua directed antibody 2F8 (Kehe et al. 2013; van der Schans et al. 1994). In slot blot analyses using this antibody, statistically significant adduct induction in isolated DNA was revealed upon treatment with $\geq 100 \mu \mathrm{M} \mathrm{SM}$ and $\geq 500 \mu \mathrm{M}$ CEES treatment, which corresponds to difference of a 3-4 order of magnitudes compared to the MS method. Furthermore, it is evident that the 2F8 antibody is not completely specific for $N 7$-HETE-Gua adducts, as detection of adducts induced by CEES, SM, and nitrogen mustards, in DNA as well as in RNA was reported (Mangerich et al. 2016). Moreover, it is not clear whether the antibody detects only mono-alkylated guanine or additionally Bis-Gua adducts or even adenine adducts, as it was produced in rabbits after injecting complete SM-treated CT-DNA.

Based on radioactive-labeling techniques, SM-induced DNA adducts were reported previously at frequencies of $\sim 61 \%$ N7-HETE-Gua, 17\% Bis-Gua, 16\% N3-HETEAde, and $0.1 \%, O^{6}$-HETE-Gua (Lawley and Brookes 1967; Ludlum et al. 1986, 1994). This implicated about three times more mono-alkylated guanine adducts compared to Bis-Gua
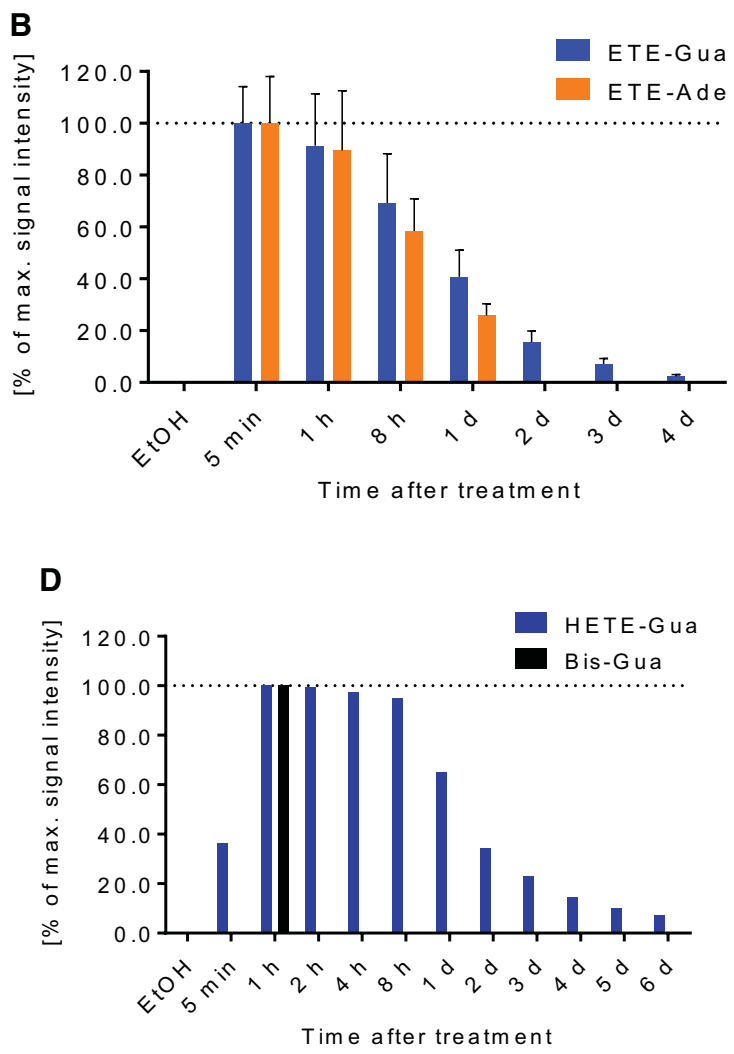

6 days post-treatment. c, d After SM treatment, peak adduct levels were observed by $1 \mathrm{~h}$ after treatment and adduct levels remained at a higher level as compared to CEES-treated cells. Data in $\mathbf{a}$ and $\mathbf{b}$ represent means \pm SEM of three independent experiments. Data in $\mathbf{c}$ and d are from one experiment

and mono-alkylated adenine adducts, respectively. Recently, LC-MS/MS-based studies reported a higher percentage of mono-alkylated guanine $(\sim 81 \%)$ and lower proportions of Bis-Gua $(\sim 12 \%)$ and mono-alkylated adenine $(\sim 6 \%)$ in SMtreated isolated CT-DNA (Batal et al. 2013a). Notably, in the same study, CEES induced almost exclusively monoalkylated guanine adducts $(\sim 98 \%)$. Somewhat contrary, in our study, mono-alkylated guanine adducts in CT-DNA constituted $\sim 80 \%$ after SM treatment, but only $\sim 60 \%$ after CEES treatment. Thus, SM induced four times more monoalkylated guanine adducts than mono-alkylated adenine adducts, while CEES induced only 1.5-fold more guanine adducts compared to adenine adducts. In comparison, Batal et al. found 13-fold more HETE-Gua than HETE-Ade, suggesting a higher percentage of adenine adducts in our study. SM treatment of isolated DNA led to the discovery of two DNA crosslinks, i.e., Gua-ETE-Ade and Bis-Ade, both of which were also detectable at low levels in cells and, to the best of our knowledge, have not been reported before. While these adducts occur only at low levels and are not well suited as biomarkers of exposure, they may have significant 

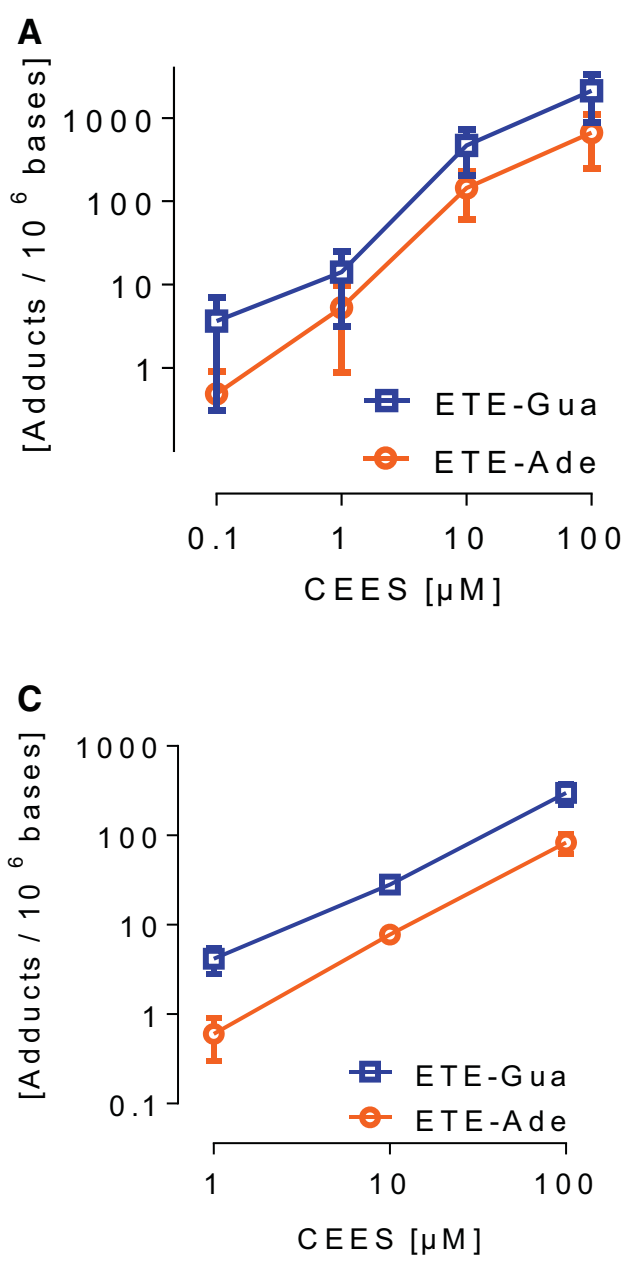

Fig. 8 Analysis of DNA nucleobase adducts isolated from SM and CEES-treated primary cells. a Freshly isolated human PBMCs were treated with the indicated concentrations of CEES for $1 \mathrm{~h}$. Adducts were detectable at concentrations $\geq 100 \mathrm{nM}$ CEES. b PBMCs were treated with $10 \mu \mathrm{M}$ CEES for $5 \mathrm{~min}$ and further incubated for the indicated periods. After 2 days, only a moderate decrease of adducts was detectable. c NHEKs were treated with the indicated concentra-

biological consequences and high mutagenic potential, as shown previously for $O^{6}$-methyl-Gua (Thomas et al. 2015).

In cells, Batal et al. determined similar adduct levels as in isolated DNA after SM treatment, while CEES induced about $10 \%$ less mono-alkylated guanine adducts in cells than in CT-DNA (Batal et al. 2013a). In our study, SM treatment induced $\sim 90 \%$ mono-alkylated guanine adducts in $\mathrm{HaCaT}$ and A549 cells. On the other hand, CEES induced 75-95\% guanine adducts in the different cell types. Wang et al. detected, in SM-treated $\mathrm{HaCaT}$ cells, a distribution of $\sim 73 \%$ of mono-alkylated guanine, but only a minor proportion of mono-alkylated adenine of $\sim 2 \%$ and a higher percentage of Bis-Gua of $\sim 25 \%$ (Wang et al. 2015). This is equivalent to 36.5 times more HETE-Gua than HETE-Ade adducts. Comparing all examined cell lines in the study by Wang et al.,
B
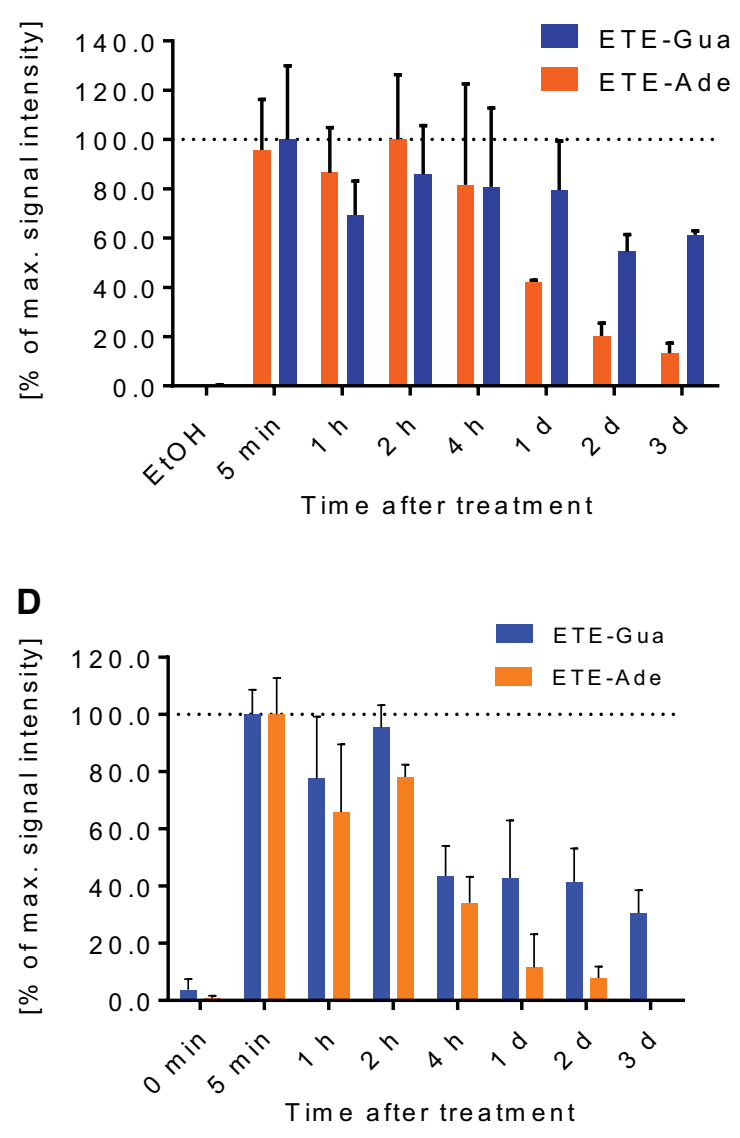

tions of CEES for $1 \mathrm{~h}$. Adducts were detectable at concentrations $\geq 1 \mu \mathrm{M}$ CEES. d NHEKs were treated with $10 \mu \mathrm{M}$ CEES for $5 \mathrm{~min}$ and further incubated for the indicated periods. After 3 days, a moderate decrease of adduct levels was detectable. Data in a represent means \pm SEM of five independent experiments. Data in $\mathbf{b}-\mathbf{d}$ represent means \pm SEM of three independent experiments

adduct levels varied considerably, i.e., 65-80\% HETE-Gua, 20-30\% Bis-Gua, and 1-2\% HETE-Ade. Taken together, the comparison of the different studies demonstrates considerable variability in adduct distributions depending on the methods and experimental systems used. To this end, it is necessary to further validate the existing methods, ideally in side-by-side comparisons, to assess adducts levels in the future with the highest possible accuracy.

Time-course analyses of DNA and RNA adducts in several cellular systems treated with sublethal doses of SM and CEES revealed rapid adduct induction directly after treatment and long persistence up to several days. Interestingly, significant differences in induction kinetics were observed between CEES- and SM-treated samples. Thus, while peak adduct levels already occurred 5 min after CEES treatment, 
Fig. 9 Analysis of SM- and CEES-induced DNA nucleobase adducts isolated from ex vivotreated human whole blood. Blood samples were treated with the indicated concentrations of CEES (a) or SM (b). Adduct induction was detectable at concentrations $\geq 100 \mathrm{nM}$ CEES and SM. $\mathbf{c}$ Interday variability of one blood donor treated with $10 \mu \mathrm{M}$ CEES. d Interindividual variability of adduct levels in blood from different donors after treatment with $10 \mu \mathrm{M}$ CEES. Data in a represent means \pm SEM of four independent experiments. Data in $\mathbf{b}$ represent means \pm SEM of three independent experiments. Data in c, $\mathbf{d}$ represent means \pm SEM of five independent experiments
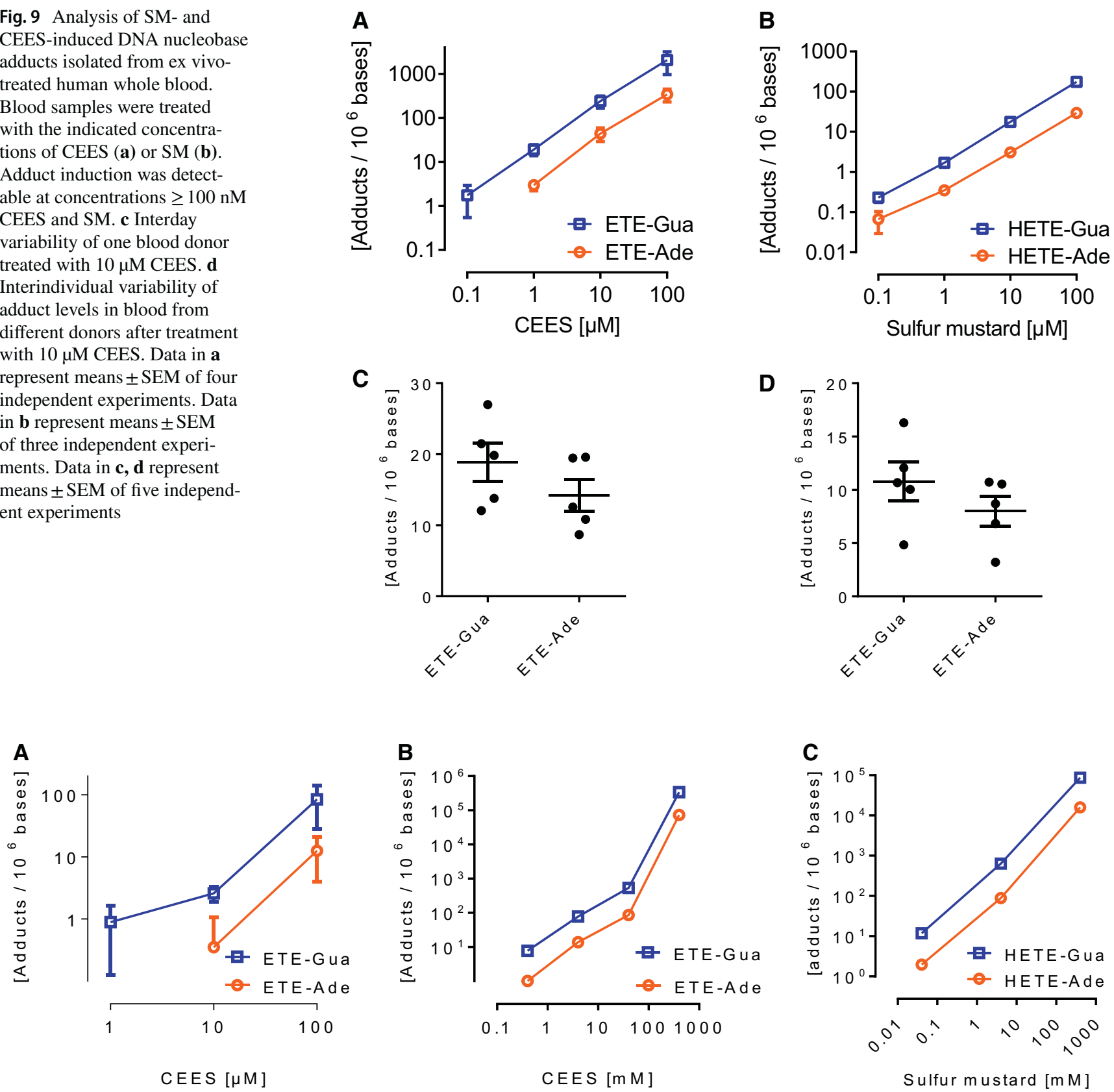

Fig. 10 Analysis of SM and CEES-induced DNA nucleobase adducts isolated from different biological matrices relevant for forensic purposes. a Dried blood spots of ex vivo CEES-treated blood samples were prepared and subsequently subjected to DNA isolation. Adduct

SM-induced adducts reached their maxima only $1 \mathrm{~h}$ after treatment. Such a delayed adduct formation in case of SM might be explained by different hydrolysis rates of CEES and SM, and/or by a delayed release of still active SM form subcellular compartments, potentially due to its altered physico-chemical properties compared to CEES. Of note, the delayed adduct formation in case of SM might represent a time frame, where SM scavengers could be applied as a induction was detectable at concentrations $\geq 1 \mu \mathrm{M}$ CEES. Analysis of adduct levels in CEES- (b) or SM- (c) ex vivo-treated rat skin. DNA adducts were detected at concentrations $\geq 400 \mu \mathrm{M}$ CEES and $\geq 40 \mu \mathrm{M} \mathrm{SM}$. a $n=3$, b, c. $n=1$

means for therapeutic intervention (Steinritz and Thiermann 2016). Our results were highly consistent with other MSbased methods, which revealed that SM-induced adducts are detectable for at least 14 days (Yue et al. 2015) or 21 days (Batal et al. 2014) in internal organs, or even 29 days in urine (Zhang et al. 2014). Wang et al. reported similar $\tau_{1 / 2}$ values in HaCaT cells of $46.6 \mathrm{~h}$ for HETE-Gua and Bis-Gua and $21.5 \mathrm{~h}$ for HETE-Ade (Wang et al. 2015), which are in 
the same range as values from our study. Of note, here, we demonstrate that SM-induced RNA adducts may also serve as candidate biomarkers of SM exposure. Thus, high RNA adduct levels were observed in isolated RNA, as well as cellular RNA, and adducts were at least as stable as DNA adducts over the examined periods of several days.

As DNA repair might be altered in immortalized cell lines, we also monitored adduct levels over time in several primary cell systems. PBMCs were very sensitive against CEES, as they showed high induction of cell death as well as high adduct levels compared to cell lines and NHEKs. Here, again, adduct levels decayed slowly, suggesting slow turnover and/or inefficient repair of such adducts. Indeed, various repair-resistant DNA adducts have been reported in the literature, e.g., several bulky adducts were shown to be poor substrates for DNA repair (Geacintov and Broyde 2017). Furthermore, some populations of PBMCs exhibit impaired DNA repair, e.g., monocytes are impaired in base excision repair (BER) and double strand break repair (DSB) repair (Bauer et al. 2011). Experiments with repair-deficient cells showed that BER-deficient cells are only sensitive to the mono-alkylating CEES, whereas nucleotide excision repair (NER)-deficient cells are sensitive to both, CEES and $\mathrm{SM}$, and in contrast, non-homologous end-joining (NHEJ) and homologous recombination (HR)-deficient cells are only sensitive to crosslinking SM (Jowsey et al. 2012). In addition to inefficient repair of DNA adducts, it is conceivable that subcellular lipid compartments form a reservoir for SM, which could lead to a long-lasting constant release of the reactive substance. This hypothesis is supported by the recent studies reporting the accumulation of intact SM or SM-induced DNA adducts in lipid-rich tissues (Xu et al. 2017; Yue et al. 2015). Furthermore, prolonged half-lives of SM-induced DNA adducts were seen in lipid-rich cells (Wang et al. 2015).

As it was a major aim of this study to develop an analytical platform to use SM-induced nucleic acid adducts as biomarkers in exposure verification, we performed adduct quantification in three different sample matrices that can be used for forensic purposes: first, human whole blood, as the standard sample type for biomarker analysis; second, dried blood spot of ex vivo-exposed whole blood, as dried blood spots allow easy handling of samples with regards to shipment and storage; third, (rat) skin samples, since skin biopsies can be used in sampling of potentially SM-exposed individuals, due to higher concentrations of analytes than in blood (although this sampling method is more invasive than blood collection). In all three cases, adduct detection was achieved with highly satisfactory sensitivities, which will allow SM exposure verification in authentic sample material. Thus, SM doses of Iranian victims were exposed to, corresponded to experimental treatment doses of ex vivotreated blood of 0.4-1.8 $\mu \mathrm{M}$ SM (Noort et al. 1999). In our study, we could detect nucleobase adducts in human whole blood at treatment concentration of $0.1 \mu \mathrm{M}$ SM. In the dried blood spot analysis, adducts could be clearly detected at treatment concentrations $\geq 1 \mu \mathrm{M}$ CEES. Based on our data from in vitro test systems, showing that CEES and SM exposure was detected at similar treatment concentrations, it is expected that this sensitivity level also holds true for SM. In rat skin, the lowest tested dose was $40 \mu \mathrm{M}$ SM. As concentrations of reactive SM are considered much lower in the blood stream compared to the skin, which is in direct contact with the agent, the higher detection limit in the skin samples will still be suitable for the verification of SM exposure in authentic sample material. Thus, all three matrices proved to be suitable to verify SM exposure.

In conclusion, in the present study, we have developed, validated, and applied a robust and versatile bioanalytical platform for the quantitation of CEES and SM-induced nucleic acid damage in relevant biological sample matrices. The UPLC-MS/MS platform is currently implemented into the method portfolio of the Institute of Pharmacology and Toxicology of the Bundeswehr, which is a laboratory designated by the OPCW for biomedical verification. This has already led to the first applications in follow-up research projects (Tsoutsoulopoulos et al., manuscript in preparation). Furthermore, in the future, this will enable exposure verification and pathological risk assessment of authentic samples from potentially SM-exposed victims by $2-3$ completely independent sets of biomarkers, i.e., SM-protein adducts as well as SM-DNA/RNA adducts.

Acknowledgements We thank Waltraud Burckhardt-Boer and Jennifer Kindrat for valuable technical assistance. Furthermore, we thank the Proteomics and the FACS facilities of the University of Konstanz for their support.

Author contributions Conceptualization, TZ, HJ, DS, AS, AB, and $\mathrm{AM}$; methodology, TZ, SK, AB, and AM; investigation, TZ and SK; writing — original draft, TZ, and AM; writing — review and editing, TZ, $\mathrm{SK}, \mathrm{HJ}$, DS, AS, AB, and AM; supervision, project administration, and funding acquisition, $\mathrm{AB}$ and $\mathrm{AM}$.

Funding This work was funded by a research grant of the German Ministry of Defense (Bundesministerium der Verteidigung) (Grant number E/U2CB/EA199/EF552) and the German Research Foundation (DFG, Grant number INST 38/537-1). TZ was supported by a fellowship of the DFG-funded Konstanz Research School Chemical Biology (KoRS-CB).

\section{References}

Adair FE, Bagg HJ (1931) Experimental and clinical studies on the treatment of cancer by dichlorethylsulphide (mustard gas. Ann Surg 93(1):190-199

Balali-Mood M, Hefazi M (2005) The pharmacology, toxicology, and medical treatment of sulphur mustard poisoning. 
Fundam Clin Pharmacol 19(3):297-315. https://doi.org/10.11 11/j.1472-8206.2005.00325.x

Batal M, Boudry I, Cléry-Barraud C, Mouret S, Douki T (2013a) Relative yields of monomeric and dimeric adducts induced by sulphur mustard in isolated and cellular DNA as determined by HPLC/tandem mass spectrometry. Toxicol Environ Chem 95(2):260-276. https://doi.org/10.1080/02772248.2012.758729

Batal M, Boudry I, Mouret S et al (2013b) Temporal and spatial features of the formation of DNA adducts in sulfur mustardexposed skin. Toxicol Appl Pharmacol 273(3):644-650. https ://doi.org/10.1016/j.taap.2013.10.010

Batal M, Boudry I, Mouret S et al (2014) DNA damage in internal organs after cutaneous exposure to sulphur mustard. Toxicol Appl Pharmacol 278(1):39-44. https://doi.org/10.1016/j. taap.2014.04.003

Battista H-J, von Meyer L, Wehinger G (1996) Quality assurance in forensic toxicological analysis. Accred Qual Assur 1(5):201206. https://doi.org/10.1007/s007690050068

Bauer M, Goldstein M, Christmann M, Becker H, Heylmann D, Kaina B (2011) Human monocytes are severely impaired in base and DNA double-strand break repair that renders them vulnerable to oxidative stress. Proc Natl Acad Sci 108(52):21105

Cheung-Ong K, Giaever G, Nislow C (2013) DNA-damaging agents in cancer chemotherapy: serendipity and chemical biology. Chem Biol 20(5):648-659. https://doi.org/10.1016/j.chemb iol.2013.04.007

Deans AJ, West SC (2011) DNA interstrand crosslink repair and cancer. Nat Rev Cancer 11(7):467-480

Doi M, Hattori N, Yokoyama A et al (2011) Effect of mustard gas exposure on incidence of lung cancer: a longitudinal study. Am J Epidemiol 173(6):659-666. https://doi.org/10.1093/aje/kwq42 6

Dons D (2013) As Syria crisis mounts, scientist looks back at last major chemical attack. Science 341(6150):1051. https://doi.org/10.1126/ science.341.6150.1051

Einhorn J (1985) Nitrogen mustard: the origin of chemotherapy for cancer. Int J Radiat Oncol Biol Phys 11(7):1375-1378. https:// doi.org/10.1016/0360-3016(85)90254-8

EMA (2011) Guideline on bioanalytical method validation. EMEA/ CHMP/EWP/192217/2009. http://www.ema.europa.eu/docs/ en_GB/document_library/Scientific_guideline/2011/08/WC500 109686.pdf. Accessed 21 July 2011

FDA (2005) Q2 (R1) validation of analytical procedures: text and methodology. https://www.fda.gov/Drugs/GuidanceComplianceRe gulatoryInformation/Guidances/ucm265700.htm. Accessed Nov 2005

Gandor F, Gawlik M, Thiermann H, John H (2015) Evidence of sulfur mustard exposure in human plasma by LC-ESI-MS-MS detection of the albumin-derived alkylated HETE-CP dipeptide and chromatographic investigation of its cis/trans isomerism. J Anal Toxicol 39(4):270-279. https://doi.org/10.1093/jat/bkv010

Geacintov NE, Broyde S (2017) Repair-resistant DNA lesions. Chem Res Toxicol 30(8):1517-1548. https://doi.org/10.1021/acs.chemr estox.7b00128

Hoenig SL (2002) Handbook of chemical warfare and terrorism. Greenwood Publishing Group, Westport

Hosseini-khalili A, Haines DD, Modirian E et al (2009) Mustard gas exposure and carcinogenesis of lung. Mutat Res 678(1):1-6. https ://doi.org/10.1016/j.mrgentox.2009.05.022

Iyer SS, Zhang Z-P, Kellogg GE, Karnes HT (2004) Evaluation of deuterium isotope effects in normal-phase LC-MS-MS separations using a molecular modeling approach. J Chromatogr Sci 42(7):383-387. https://doi.org/10.1093/chromsci/42.7.383

John H, Siegert M, Gandor F et al (2016a) Optimized verification method for detection of an albumin-sulfur mustard adduct at Cys(34) using a hybrid quadrupole time-of-flight tandem mass spectrometer after direct plasma proteolysis. Toxicol Lett 244:103-111. https://doi.org/10.1016/j.toxlet.2015.09.027

John H, Willoh S, Hormann P, Siegert M, Vondran A, Thiermann H (2016b) Procedures for analysis of dried plasma using microsampling devices to detect sulfur mustard-albumin adducts for verification of poisoning. Anal Chem 88(17):8787-8794. https://doi. org/10.1021/acs.analchem.6b02199

Jowsey PA, Williams FM, Blain PG (2012) DNA damage responses in cells exposed to sulphur mustard. Toxicol Lett 209(1):1-10. https ://doi.org/10.1016/j.toxlet.2011.11.009

Kehe K, Balszuweit F, Emmler J, Kreppel H, Jochum M, Thiermann H (2008a) Sulfur mustard research - strategies for the development of improved medical therapy. Eplasty 8:e32

Kehe K, Raithel K, Kreppel H, Jochum M, Worek F, Thiermann H (2008b) Inhibition of poly(ADP-ribose) polymerase (PARP) influences the mode of sulfur mustard (SM)-induced cell death in HaCaT cells. Arch Toxicol 82(7):461-470. https://doi. org/10.1007/s00204-007-0265-7

Kehe K, Balszuweit F, Steinritz D, Thiermann H (2009) Molecular toxicology of sulfur mustard-induced cutaneous inflammation and blistering. Toxicology 263(1):12-19. https://doi.org/10.1016/j. tox.2009.01.019

Kehe K, Schrettl V, Thiermann H, Steinritz D (2013) Modified immunoslotblot assay to detect hemi and sulfur mustard DNA adducts. Chemico Biol Interact 206(3):523-528. https://doi.org/10.1016/j. cbi.2013.08.001

Krumbhaar EB (1919) Rôle of the blood and the bone marrow in certain forms of gas poisoning: I. Peripheral blood changes and their significance. J Am Med Assoc 72(1):39-41. https://doi. org/10.1001/jama.1919.26110010018009f

Lawley PD, Brookes P (1967) Interstrand cross-linking of DNA by difunctional alkylating agents. J Mol Biol 25(1):143-160

Liu C, Liang L, Xiang Y et al (2015) An improved method for retrospective quantification of sulfur mustard exposure by detection of its albumin adduct using ultra-high pressure liquid chromatography-tandem mass spectrometry. Anal Bioanal Chem 407(23):7037-7046. https://doi.org/10.1007/s00216-015-8842-8

Ludlum DB, Kent S, Mehta JR (1986) Formation of O6-ethylthioethylguanine in DNA by reaction with the sulfur mustard, chloroethyl sulfide, and its apparent lack of repair by $O 6$-alkylguanine-DNA alkyltransferase. Carcinogenesis 7(7):1203-1206

Ludlum DB, Austin-Ritchie P, Hagopian M, Niu TQ, Yu D (1994) Detection of sulfur mustard-induced DNA modifications. Chemico Biol Interact 91(1):39-49

Mangerich A, Esser C (2014) Chemical warfare in the First World War: reflections 100 years later. Arch Toxicol 88(11):1909-1911. https ://doi.org/10.1007/s00204-014-1370-z

Mangerich A, Debiak M, Birtel M et al (2016) Sulfur and nitrogen mustards induce characteristic poly(ADP-ribosyl)ation responses in $\mathrm{HaCaT}$ keratinocytes with distinctive cellular consequences. Toxicol Lett 244:56-71. https://doi.org/10.1016/j.toxlet.2015.09.010

Mukaida K, Hattori N, Iwamoto H et al (2017) Mustard gas exposure and mortality among retired workers at a poisonous gas factory in Japan: a 57-year follow-up cohort study. Occup Environ Med 74(5):321-327. https://doi.org/10.1136/oemed-2015-103437

Newmark J, Langer JM, Capacio B, Barr J, McIntosh RG (2007) Liquid sulfur mustard exposure. Mil Med 172(2):196-198

Noort D, Hulst AG, de Jong LP, Benschop HP (1999) Alkylation of human serum albumin by sulfur mustard in vitro and in vivo: mass spectrometric analysis of a cysteine adduct as a sensitive biomarker of exposure. Chem Res Toxicol 12(8):715-721. https ://doi.org/10.1021/tx9900369

Noort D, Fidder A, Degenhardt-Langelaan CE, Hulst AG (2008) Retrospective detection of sulfur mustard exposure by mass spectrometric analysis of adducts to albumin and hemoglobin: an in vivo study. J Anal Toxicol 32(1):25-30 
Tabassi LW (ed) (2015) OPCW: the legal texts, 3rd edn. T.M.C. Asser Press, The Hague, The Netherlands

OPCW (2017). https://www.opcw.org/fileadmin/OPCW/EC/M-55/en/ ecm55nat01r2_e_.pdf. Accessed 5 July 2017

Pappenheimer AM, Vance M (1920) The effects of intravenous injections of dichloroethylsulfide in rabbits, with special reference to its leucotoxic action. J Exp Med 31(1):71-94

Remane D, Wissenbach DK, Peters FT (2016) Recent advances of liquid chromatography-(tandem) mass spectrometry in clinical and forensic toxicology—an update. Clin Biochem 49(13-14):10511071. https://doi.org/10.1016/j.clinbiochem.2016.07.010

Shakarjian MP, Heck DE, Gray JP et al (2010) Mechanisms mediating the vesicant actions of sulfur mustard after cutaneous exposure. Toxicol Sci 114(1):5-19. https://doi.org/10.1093/toxsci/kfp253

Steinritz D, Thiermann H (2016) Sulfur mustard. In: Brent J, Burkhart K, Dargan P, Hatten B, Megarbane B, Palmer R (eds) Critical care toxicology. Springer International Publishing, Cham, pp 1-30

Steinritz D, Striepling E, Rudolf KD et al (2016) Medical documentation, bioanalytical evidence of an accidental human exposure to sulfur mustard and general therapy recommendations. Toxicol Lett 244:112-120. https://doi.org/10.1016/j.toxlet.2015.08.1105

Stokvis E, Rosing H, Beijnen JH (2005) Stable isotopically labeled internal standards in quantitative bioanalysis using liquid chromatography/mass spectrometry: necessity or not? Rapid Commun Mass Spectrom 19(3):401-407 https://doi.org/10.1002/rcm.1790

Thiermann H, Worek F, Kehe K (2013) Limitations and challenges in treatment of acute chemical warfare agent poisoning. Chemico Biol interact 206(3):435-443. https://doi.org/10.1016/j. cbi.2013.09.015

Thomas AD, Fahrer J, Johnson GE, Kaina B (2015) Theoretical considerations for thresholds in chemical carcinogenesis. Mutat Res Rev Mutat Res 765:56-67. https://doi.org/10.1016/j.mrrev .2015.05.001

Tretyakova N, Goggin M, Sangaraju D, Janis G (2012) Quantitation of DNA adducts by stable isotope dilution mass spectrometry. Chem Res Toxicol 25(10):2007-2035. https://doi.org/10.1021/ tx3002548

United Nations Treaty Collection (1992). https://treaties.un.org/Pages $/$ ViewDetails.aspx?src=TREATY\&mtdsg_no $=$ XXVI-3\&chapt er $=26 \&$ lang=en. Accessed 3 Sept 1992 van der Schans GP, Scheffer AG, Mars-Groenendijk RH, Fidder A, Benschop HP, Baan RA (1994) Immunochemical detection of adducts of sulfur mustard to DNA of calf thymus and human white blood cells. Chem Res Toxicol 7(3):408-413

Vedder EB (1925) The present status of chlorine gas therapy. Trans Am Climatol Clin Assoc 41:203-216

Wang Z (2010) Levinstein process comprehensive organic name reactions and reagents. Wiley, New York

Wang P, Zhang Y, Chen J et al (2015) Analysis of different fates of DNA adducts in adipocytes post-sulfur mustard exposure in vitro and in vivo using a simultaneous UPLC-MS/MS quantification method. Chem Res Toxicol 28(6):1224-1233. https://doi. org/10.1021/acs.chemrestox.5b00055

Xu B, Zong C, Zhang Y et al (2017) Accumulation of intact sulfur mustard in adipose tissue and toxicokinetics by chemical conversion and isotope-dilution liquid chromatography-tandem mass spectrometry. Arch Toxicol 91(2):735-747. https://doi.org/10.1007/ s00204-016-1774-Z

Yue L, Wei Y, Chen J et al (2014) Abundance of four sulfur mustardDNA adducts ex vivo and in vivo revealed by simultaneous quantification in stable isotope dilution-ultrahigh performance liquid chromatography-tandem mass spectrometry. Chem Res Toxicol 27(4):490-500. https://doi.org/10.1021/tx4003403

Yue L, Zhang Y, Chen J et al (2015) Distribution of DNA adducts and corresponding tissue damage of Sprague-Dawley rats with percutaneous exposure to sulfur mustard. Chem Res Toxicol 28(3):532-540. https://doi.org/10.1021/tx5004886

Zhang Y, Yue L, Nie Z et al (2014) Simultaneous determination of four sulfur mustard-DNA adducts in rabbit urine after dermal exposure by isotope-dilution liquid chromatography-tandem mass spectrometry. J Chromatogr B Anal Technol Biomed Life Sci 961:29-35. https://doi.org/10.1016/j.jchromb.2014.04.050

Zubel T, Burkle A, Mangerich A (2018) Mass spectrometric analysis of sulfur mustard-induced biomolecular adducts: are DNA adducts suitable biomarkers of exposure? Toxicol Lett 293:21-30. https ://doi.org/10.1016/j.toxlet.2017.12.014 